\title{
Embryonic stem cell differentiation: emergence of a new era in biology and medicine
}

\author{
Gordon Keller ${ }^{1}$ \\ Department of Gene and Cell Medicine, Mount Sinai School of Medicine, New York, New York 10029, USA
}

The discovery of mouse embryonic stem (ES) cells $>20$ years ago represented a major advance in biology and experimental medicine, as it enabled the routine manipulation of the mouse genome. Along with the capacity to induce genetic modifications, ES cells provided the basis for establishing an in vitro model of early mammalian development and represented a putative new source of differentiated cell types for cell replacement therapy. While ES cells have been used extensively for creating mouse mutants for more than a decade, their application as a model for developmental biology has been limited and their use in cell replacement therapy remains a goal for many in the field. Recent advances in our understanding of ES cell differentiation, detailed in this review, have provided new insights essential for establishing ES cell-based developmental models and for the generation of clinically relevant populations for cell therapy.

Embryonic stem (ES) cells are pluripotent cells derived from the inner cell mass of blastocyst-stage embryos (Evans and Kaufman 1981; Martin 1981). Their importance to modern biology and medicine derives from two unique characteristics that distinguish them from all other organ-specific stem cells identified to date. First, they can be maintained and expanded as pure populations of undifferentiated cells for extended periods of time, possibly indefinitely, in culture. Unlike transformed tumor cell lines, ES cells can retain normal karyotypes following extensive passaging in culture. Second, they are pluripotent, possessing the capacity to generate every cell type in the body. The pluripotent nature of mouse ES cells was formally demonstrated by their ability to contribute to all tissues of adult mice, including the germline, following their injection into host blastocysts (Bradley et al. 1984). In addition to their developmental potential in vivo, ES cells display a remarkable capacity to form differentiated cell types in culture

[Keywords: ES cells; differentiation; mesoderm; endoderm; ectoderm; embryonic development]

${ }^{1}$ Correspondence.

E-MAIL gordon.keller@mssm.edu; FAX (212) 803-6740.

Article and publication are at http://www.genesdev.org/cgi/doi/10.1101/ gad. 1303605
(Keller 1995; Smith 2001). Studies during the past 20 years have led to the development of appropriate culture conditions and protocols for the generation of a broad spectrum of lineages. The ability to derive multiple lineages from ES cells opens exciting new opportunities to model embryonic development in vitro for studying the events regulating the earliest stages of lineage induction and specification. Comparable studies are difficult in the mouse embryo and impossible in the human embryo. In addition to providing a model of early development, the ES cell differentiation system is viewed by many as a novel and unlimited source of cells and tissues for transplantation for the treatment of a broad spectrum of diseases. The isolation of human ES cells (hES) in 1998 dramatically elevated the interest in the cell therapy aspect of ES cells and moved this concept one step closer to reality (Thomson et al. 1998). This review details the current status of mouse and human ES cell differentiation from both the developmental biology and cell replacement perspectives. The first sections of the review highlight successes to date in the generation and characterization of mature populations, while the final section outlines the challenges for the future with a focus on the identification of progenitor cells representing the earliest stages of embryonic lineage development. The reader is referred to other recent reviews that provide additional details for many of the subjects covered here (Kyba and Daley 2003; Nir et al. 2003; Hornstein and Benvenisty 2004; Lang et al. 2004; Pera and Trounson 2004; Rippon and Bishop 2004; West and Daley 2004). For the purpose of this review, the term ES will be used in reference to mouse cells and hES for human cells.

\section{Maintaining undifferentiated ES cells}

ES cells were initially established and maintained by coculture with mouse embryonic feeder cells (Evans and Kaufman 1981; Martin 1981). Subsequent studies identified leukemia inhibitory factor (LIF) as one of the feeder-cell-derived molecules that plays a pivotal role in the maintenance of these cells (Smith et al. 1988; Williams et al. 1988; Stewart et al. 1992). In the presence of appropriate batches of fetal calf serum (FCS), recombinant LIF can replace the feeder cell function and sup- 
port the growth of undifferentiated ES cells (Smith et al. 1988; Williams et al. 1988). Recently, Ying et al. (2003a) have uncovered a role for BMP4 in ES cell growth and demonstrated that in the presence of LIF, it can replace the requirement for serum. With these new developments, it is now possible to grow ES cells with defined factors in the absence of serum or feeder cells. Molecular analyses have revealed that LIF functions through the gp130 activation of STAT3 (Niwa et al. 1998; Matsuda et al. 1999), whereas the effect of BMP4 on undifferentiated ES cells is mediated by Smad activation and the subsequent induction of the helix-loop-helix Id factors. In addition to STAT3 and Id, two other transcription factors, Oct3/4 (Niwa et al. 2000) and nanog (Chambers et al. 2003; Mitsui et al. 2003), have been shown to play pivotal roles in maintaining the undifferentiated state of ES cells. The role of these transcription factors in ES cell renewal has been recently reviewed (Chambers and Smith 2004) and will not be discussed further here.

The regulation of hES cell growth is less well understood and differs from that of the mouse in that LIF and STAT3 appear to play no role in their self-renewal (Thomson et al. 1998; Reubinoff et al. 2000; Daheron et al. 2004). With current protocols, hES cells can be maintained on feeder cells in serum-free medium supplemented with bFGF (Amit et al. 2000). hES cells can also be grown in the absence of feeder cells, if cultured on matrigel- or laminin-coated plates in medium supplemented with mouse embryonic fibroblast conditioned medium (MEF CM) (Xu et al. 2001). While not as well defined as the conditions for the growth of mouse cells, this protocol does provide for relatively easy maintenance of hES cell populations. Cells grown in these conditions for $>100$ population doublings retained normal karyotypes and stem cell characteristics, including their in vitro and in vivo pluripotent differentiation potential. Recently, Sato et al. (2004) demonstrated that activation of the canonical Wnt pathway could replace the requirement of MEF CM in the maintenance of undifferentiated hES cells for short periods of time (5-7 d). Whether or not Wnt signaling has an effect on hES cell self-renewal over longer periods through multiple passages remains to be determined. hES cells do express both Oct4 (Ginis et al. 2004) and nanog (Daheron et al. 2004; Richards et al. 2004; Sato et al. 2004), suggesting that this aspect of their regulation may be similar to that observed in mouse ES cells. Future studies will no doubt define specific molecules for the maintenance of hES cells and uncover the molecular mechanisms that regulate their self-renewal.

\section{Differentiation of ES cells in culture}

When removed from the factors that maintain them as stem cells, ES cells will differentiate and, under appropriate conditions, generate progeny consisting of derivatives of the three embryonic germ layers: mesoderm, endoderm, and ectoderm (Keller 1995; Smith 2001). Wild-type ES cells do not differentiate to trophectoderm in culture and, in this respect, reflect the potential of their founder embryonic population, the inner cell mass
(Fig. 1). hES cells differ from mouse cells in this respect, as when induced with BMP4, they will give rise to cells that display characteristics of the trophoblast lineage $(\mathrm{Xu}$ et al. 2002). The reason for this difference is not clear, but may indicate that at least some of the hES cell lines represent earlier stages of development than the comparable mouse populations.

Three general approaches, outlined in Figure 2, are used to initiate ES cell differentiation. With the first method, ES cells are allowed to aggregate and form threedimensional colonies known as embryoid bodies (EBs) (Doetschman et al. 1985; Keller 1995). In the second method, ES cells are cultured directly on stromal cells, and differentiation takes place in contact with these cells (Nakano et al. 1994). The most commonly used stromal cell line for such differentiation studies is OP9 (Nakano et al. 1994), originally isolated from CSF-1deficient op/op mice (Yoshida et al. 1990). The third protocol involves differentiating ES cells in a monolayer on extracellular matrix proteins (Nishikawa et al. 1998).

All three approaches to ES cell differentiation are effective and have specific advantages and disadvantages. EBs offer the advantage of providing a three-dimensional structure that enhances cell-cell interactions that may be important for certain developmental programs. The complexity of the EBs can also be a disadvantage as the generation of cytokines and inducing factors within these structures can complicate interpretations of experiments in which one is trying to understand the signaling pathways involved in lineage commitment. Coculture with stromal cells provides the beneficial growth promoting effects of the particular cell line used. However, undefined factors produced by these supportive cells may influence the differentiation of the ES cells to undesired cell types. An additional problem with this method is the difficulty that can be encountered when attempting to separate the ES-cell-derived cells from the stromal cells. Differentiation in monolayers on known substrates can minimize the influence of neighboring

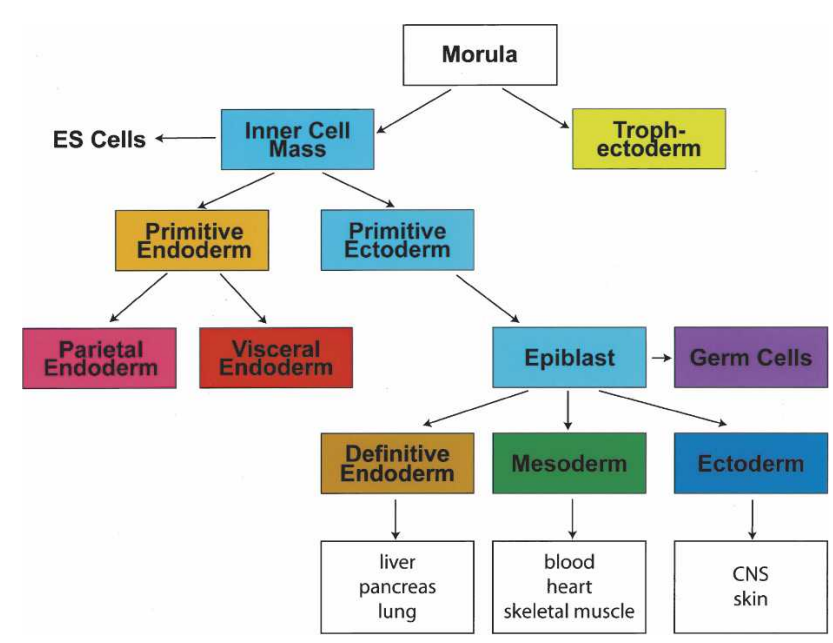

Figure 1. Scheme of early mouse development depicting the relationship of early cell populations to the primary germ layers. 


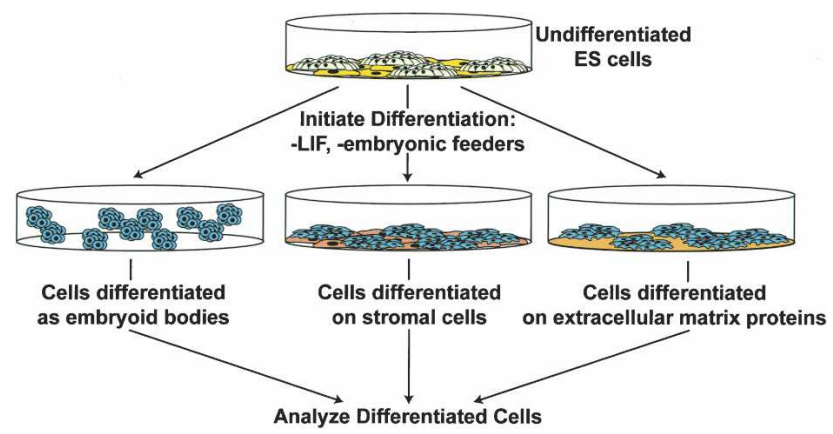

Figure 2. Three different protocols used for ES cell differentiation.

cells and supportive stromal cells and in this regard is one of the simplest protocols. With this protocol the matrix proteins are critical, and different proteins may dramatically influence the generation and survival of the developing cell types.

Three criteria should be considered when using the ES cell model for lineage-specific differentiation. First, protocols need to be established that promote the efficient and reproducible development of the cell type of interest. If possible, selection strategies should be combined with optimal differentiation schemes to enable the isolation of highly enriched cell populations. Second, lineage development from ES cells should recapitulate the developmental program that establishes the lineage in the early embryo. Third, the mature cell populations that develop in these cultures must display appropriate functional properties both in culture and when transplanted into appropriate animal models.

The three differentiation methods described above have been used to generate a broad spectrum of cell types from ES cells (Keller 1995; Smith 2001). For lineages that have been studied in detail, the first two criteria outlined above have been met as efficient protocols for their differentiation have been established and the sequence of events leading to their development in culture was found to faithfully recapitulate those in the early embryo. The third aim has yet to be fulfilled for most populations and represents one of the major challenges in the field today. Since their derivation, progress has been made with the differentiation of hES cells. Although not nearly as advanced as the studies with the mouse system, the findings to date indicate that it will be possible to generate a broad spectrum of cell types from them in culture (Schuldiner et al. 2000; Odorico et al. 2001; Pera and Trounson 2004).

Many differentiation protocols have been optimized using FCS as a growth supplement and/or as a source of inducing factors. Although these approaches have been successful for the development of certain lineages, the use of FCS has several serious drawbacks that include batch-to-batch variability and the lack of identity of the inducing factors contained in it. As discussed in a later section of this review, several recent studies have eliminated serum and have begun to identify factors required for lineage-specific differentiation. As more protocols in- corporate these approaches, both mouse and human ES cell multilineage differentiation will become a routine technology in many labs.

\section{Differentiated cell types from ES cells}

\section{Mesoderm-derived lineages}

Mesoderm-derived lineages, including the hematopoietic, vascular, and cardiac, are among the easiest to generate from ES cells and have been studied in considerable detail. Of these, hematopoietic development is the best characterized. Findings from several different studies have demonstrated striking parallels between the ES cell model and the early embryo, providing important insights into the embryonic origins of the hematopoietic system. Given these findings, hematopoietic development is covered in the greatest detail in this review.

\section{Hematopoietic development}

Following the initial studies demonstrating the presence of hemoglobinized cells in EBs (Doetschman et al. 1985), there was significant interest in modeling various aspects of hematopoietic commitment using the ES cell differentiation model (Burkert et al. 1991; Schmitt et al. 1991; Keller et al. 1993; Nakano et al. 1994). One of the initial goals of many investigators in the field was to generate hematopoietic stem cells (HSCs) from ES cells with the aim of developing a readily accessible supply of transplantable stem cells. HSCs are typically assayed by their ability to provide long-term multilineage hematopoietic repopulation following intravenous (IV) transplantation into hematopoietically deficient animals (Kondo et al. 2003). For a stem cell to function in this assay, it must be multipotent and possess the capacity to home to the bone marrow following transplantation. Despite extensive efforts by many groups during the past 10 years, the development of HSCs from ES cells remains a challenge as most attempts to identify these cells in the differentiation cultures have failed (Muller and Dzierzak 1993; G. Lacaud, V. Kouskoff, M. Kennedy, and G. Keller, unpubl.). These failures prompted a re-evaluation of hematopoietic commitment in the ES cell differentiation cultures from the perspective of hematopoiesis in the early embryo. Patterning hematopoietic development of ES cells in culture on hematopoietic commitment in the early embryo was important as the hematopoietic system undergoes dramatic changes throughout embryonic life (Metcalf and Moore 1971; Russel 1979; Keller et al. 1999). These changes need to be reproduced in the ES cell system if it is to be a valid model of early development and ultimately a source of HSCs.

\section{Hematopoietic development in the embryo}

Hematopoiesis in the early embryo initiates at two independent sites, the yolk sac and an intraembryonic region known as the para-aortic splanchnopleura (P-Sp), 
which later contains the developing aorta, gonads, and mesonephros (AGM) (Dieterlen-Lievre 1975; Russel 1979; Godin et al. 1995; Medvinsky and Dzierzak 1996; Palis et al. 1999). Detailed analysis of hematopoietic development in the early embryo strongly suggests that the programs generated in these two regions are different. Hematopoietic commitment is detected first in the yolk sac, where distinct blood islands appear, shortly following gastrulation (Moore and Metcalf 1970; Haar and Ackerman 1971; Palis et al. 1995, 1999). These blood islands consist of an inner cluster of maturing erythrocytes surrounded by a layer of developing endothelial cells (Haar and Ackerman 1971). The erythroid cells within these blood islands, known as primitive erythrocytes, are distinct from fetal and adult erythrocytes in that they are large, circulate in the bloodstream as nucleated cells for much of their life span, and contain an embryonic form of hemoglobin (Barker 1968; Brotherton et al. 1979; Russel 1979; Kingsley et al. 2004). Production of primitive erythrocytes is known as primitive erythropoiesis and is restricted to the yolk sac during a narrow window of development in the mouse embryo (Palis et al. 1999). Development of all other blood cell lineages including myeloid, fetal, and adult erythroid and lymphoid is referred to as definitive hematopoiesis. Definitive erythroid cells enucleate prior to entering the bloodstream, are smaller than those of the primitive lineage, and produce adult forms of hemoglobin.

In addition to primitive erythrocytes, the yolk sac generates a subset of lineages from the definitive hematopoietic program including the macrophage, definitive erythroid, and mast cell (Palis et al. 1999). Kinetic analysis of the developing yolk sac revealed that these lineages are produced in a defined temporal pattern with primitive erythroid and macrophage appearing first, followed by definitive erythroid, which, in turn, is followed by mast cells. While the yolk sac does have potential beyond that of primitive erythropoiesis, it does not appear to be capable of generating lymphocytes or HSCs, when analyzed prior to the onset of circulation (Cumano et al. 2001). Parallel studies have demonstrated that the hematopoietic program initiated in the P-Sp includes the generation of the myeloid, lymphoid, and definitive erythroid lineages as well as the HSCs (Muller et al. 1994; Godin et al. 1995; Cumano et al. 2001). The P-Sp does not, however, generate primitive erythrocytes. Thus, the distinguishing features of the early yolk sac are the generation of the primitive erythroid lineage and a lack of lymphoid and HSC potential, while the P-Sp program can be defined by the development of the lymphoid lineages and HSCs. Collectively, these observations indicate that the hematopoietic system initiates with the production of a limited number of specialized lineages in the yolk sac and matures with time into a full multilineage system with the switch to the P-Sp. While somewhat unusual, this pattern is logical, as the system is responding to the requirements of the embryo at different developmental stages. These dramatic changes in the hematopoietic system, in particular the early and transient appearance of the primitive erythroid lineage, pro- vide a developmental map for monitoring hematopoietic commitment in the ES cell differentiation cultures.

\section{ES-cell-derived primitive and definitive hematopoiesis}

In optimized culture conditions following serum induction, ES cells will undergo hematopoietic differentiation (Keller 1995). Hematopoietic commitment within these cultures can be easily monitored by gene expression patterns (Schmitt et al. 1991; Keller et al. 1993; Robertson et al. 2000), the appearance of specific cell surface markers (Kabrun et al. 1997; Nishikawa et al. 1998), and the development of clonable progenitor cells (Schmitt et al. 1991; Keller et al. 1993). With these assays, it has been possible to demonstrate that development of the hematopoietic lineages is highly reproducible and efficient. Under appropriate culture conditions, $>50 \%$ of the cells in the differentiation cultures will express the hematopoietic/vascular receptor tyrosine kinase Flk-1 (VEGF receptor 2) (Kabrun et al. 1997) and up to 5\% can represent a clonable hematopoietic progenitor (Keller et al. 1993). Detailed analyses of the early stages of hematopoietic commitment have shown that both gene expression patterns and the kinetics of lineage development within EBs accurately reflect that found in the yolk sac (Keller et al. 1993; Palis et al. 1999; Robertson et al. 2000). Most notable was the finding that the primitive erythroid lineage develops earliest and represents a transient population that persists in the EBs for $\sim 4 \mathrm{~d}$ (Keller et al. 1993). The macrophage, definitive erythroid, and mast cell lineages appear following the onset of primitive erythropoiesis and develop in the temporal order found in the yolk sac (Keller et al. 1993). Lymphoid progenitors and HSCs have not been identified among the progeny of early stage EBs, suggesting that the initial stages of EB hematopoiesis represent the equivalent of yolk sac hematopoiesis.

The faithful recapitulation of this yolk sac developmental program provides strong evidence that regulation of hematopoietic commitment in the ES/EB model is similar, if not identical, to that of the early embryo. Support for this interpretation has been provided by gene targeting studies that helped define the role of specific transcription factors including Scl/tal-1 (Begley et al. 1989), Runx1 (Wang and Speck 1992; Ogawa et al. 1993), and GATA-1 (Orkin 1992) in the establishment of the hematopoietic system. Each of these factors functions at specific stages of blood cell differentiation as demonstrated by the observations that $\mathrm{Scl} / \mathrm{tal}-1$ is required for the development of all hematopoietic (primitive erythroid and definitive) lineages (Robb et al. 1995; Shivdasani et al. 1995), Runx1 for the definitive lineages but not primitive erythropoiesis (Okuda et al. 1996; Wang et al. 1996), and GATA-1 for late-stage primitive and definitive erythroid maturation (Pevny et al. 1991; Weiss et al. 1994). All of these defects have been accurately replicated in the ES cell differentiation model (Weiss et al. 1994; Porcher et al. 1996; Wang et al. 1996; Lacaud et al. 2002). In addition to further validating the ES cell system as a model of hematopoietic development, the ability to analyze mutations in EBs provides a powerful model for 
structure/function studies as well as for the identification of molecular targets of the gene of interest.

\section{Lymphoid and HSC development from ES cells}

While the early stages of EB differentiation do not give rise to lymphoid progeny, it has been possible to generate cells of both the T- and B-cell lineages following extended periods of time in culture. B-cell potential was demonstrated following the coculture of ES cells with OP9 stromal cells in medium containing lymphoid cytokines (Nakano et al. 1994; Cho et al. 1999). More recently Schmitt et al. (2004) demonstrated that expression of the Notch receptor ligand, delta-like 1, in the OP9 cells facilitates the differentiation of the developing lymphoid cells to a T-cell fate. These findings are encouraging as they indicate that populations similar to that of the P-Sp may be generated from differentiating ES cells and that signaling pathways, such as Notch, known to play a role in B-cell and T-cell fate in vivo may function in a similar manner in culture.

Two recent reports have provided evidence that cells with HSC properties can be generated from ES cells in culture. In the first, Kyba et al. (2002) transplanted recipient animals with ES-cell-derived hematopoietic cells that had been induced with forced expression of the HoxB4 gene. Donor cells were clearly evident in the transplanted animals up to $12 \mathrm{wk}$ following repopulation in primary recipients and as long as $20 \mathrm{wk}$ in secondary recipients. The majority of donor cells, however, appeared to be myeloid as the levels of lymphoid engraftment were very low. These patterns of repopulation differ from those generated by fetal liver or adult bone marrow HSCs that typically show extensive myeloid and lymphoid repopulation (Jordan et al. 1990; Kondo et al. 2003). Given these patterns of engraftment, it is unclear if the repopulation originates from the equivalent of a P-Sp multipotential HSC that is not sufficiently mature to display multilineage potential or from a yolk sac-like progenitor, whose ability to survive in vivo has been prolonged by the $\operatorname{HoxB} 4$ gene.

In the second study, $\mathrm{CD} 45^{+} \mathrm{c}-\mathrm{kit}^{+}$cells isolated from EBs cultured for $7-10 \mathrm{~d}$ in the presence of c-kit ligand, IL-3, and IL-6 were transplanted into irradiated recipient animals (Burt et al. 2004). Even when transplanted into allogeneic recipients, these cells generated extensive hematopoietic chimerism and contributed to both the myeloid and lymphoid lineages. These findings are somewhat surprising, given that many different hematopoietic populations from ES cell differentiation cultures have been transplanted into different types of recipients with little evidence of repopulation. One possible reason for the success in this study is that the particular batch of FCS used may have contained factors that promote the development of HSCs. Establishment of serum-free conditions for the generation of these cells would enable other investigators to reproduce these findings. One interesting observation in this study was that the level of ES-cell-derived hematopoietic contribution was significantly higher in recipients in which the cells were trans- planted directly into the femur rather than intravenously into the circulation. This observation suggests that repopulating cells generated in the ES cell differentiation cultures may not be fully differentiated and lack critical adhesion molecules that enable them to home to the bone marrow. A lack of homing potential may account for some of the failures in detecting HSCs in previous studies.

While these findings indicate that it is possible to generate cells that can persist and function in recipient animals, additional studies will be required to determine if these cells are comparable to HSCs found in the fetal liver and adult bone marrow. Given that the P-Sp is considered to be the site of HSC development in the early embryo, one important approach will be to establish conditions to generate populations comparable to the P-Sp in the ES cell differentiation cultures. Access to such cells should ultimately enable the routine generation of HSCs from ES cells.

\section{Establishment of the hematopoietic system: identification of the hemangioblast}

One of the outstanding strengths of the ES cell differentiation model is that it provides access to early developmental stages that are difficult to access in the embryo. This unique advantage has been fully exploited to investigate the earliest stages of hematopoietic commitment (Choi et al. 1998; Nishikawa et al. 1998) and to test a long-standing hypothesis that the hematopoietic and endothelial lineages develop from a common progenitor, a cell known as the hemangioblast. The hemangioblast hypothesis was put forward many years ago, based on the observation that the blood cell and endothelial lineages develop in close proximity at the same time in the yolk sac blood islands (Sabin 1920; Murray 1932; Haar and Ackerman 1971). Circumstantial evidence supporting this hypothesis was provided by studies demonstrating that immature hematopoietic and vascular cells share the expression of a large number of genes (Orkin 1992; Watt et al. 1995; Young et al. 1995; Fong et al. 1996; Takakura et al. 1998) and that specific genes are essential for the proper development of both lineages (Dickson et al. 1995; Robb et al. 1995; Shalaby et al. 1995; Shivdasani et al. 1995). Formal proof that a progenitor with properties of the hemangioblast does exist was provided by studies using the ES differentiation model (Choi et al. 1998; Nishikawa et al. 1998). Analysis of early-stage, carefully timed EBs led to the identification of a progenitor known as the blast colony-forming cell (BL-CFC) that gives rise to blast colonies consisting of hematopoietic and vascular progenitors in methylcellulose cultures in the presence of vascular endothelial growth factor (VEGF) (Kennedy et al. 1997; Choi et al. 1998). The hematopoietic component of these colonies consisted of primitive erythroid progenitors and the subset of definitive hematopoietic lineages that is found in the yolk sac, while the vascular potential included both the endothelial and vascular smooth muscle lineages (VSM) (Kennedy et al. 1997; Choi et al. 1998; Ema et al. 2003). 
Initial studies identified the BL-CFC as a transient progenitor that develops early in EBs prior to the onset of primitive erythropoiesis. Subsequent experiments have shown that it expresses the receptor tyrosine kinase Flk-1 (Faloon et al. 2000), the transcription factor Runx1 (Lacaud et al. 2002), and the mesoderm gene brachyury (Fehling et al. 2003), suggesting that this progenitor represents a subpopulation of mesoderm undergoing commitment to the hematopoietic and vascular lineages (Fig. 3). The BL-CFC does not, however, express markers associated with hematopoietic and vascular development, including CD31, VE-Cadherin (VE-cad), CD34, or c-kit (Fehling et al. 2003; M. Kennedy and G. Keller, unpubl.), a finding consistent with the interpretation that this progenitor represents the earliest stage of hematopoietic commitment.

The BL-CFC is not an artifact of the ES cell model, as a similar progenitor has recently been identified in the early mouse embryo (Huber et al. 2004). This progenitor arises in the posterior primitive streak of the embryo, coexpresses Flk-1 and brachyury, and displays the same developmental potential as the EB-derived BL-CFC (Fig. 3). Given these characteristics, this embryo-derived progenitor can be considered to be the illusive hemangioblast. The isolation and characterization of the embryo hemangioblast were made possible through the use of strategies developed for the identification of the BL-CFC in the ES/EB system, a clear demonstration that this in vitro model can provide important insights into early embryonic development.

The ES differentiation system has also been instrumental in characterizing the earliest stages of hematopoietic development, immediately following the appearance of the hemangioblast. Analyses of these ES-cellderived hematopoietic populations at different time points have revealed dynamic changes in the expression of cell surface proteins that likely reflect changes in the lineage composition of the system as well as maturation of the cells within a specific lineage (Kabrun et al. 1997; Nishikawa et al. 1998; Mikkola et al. 2003). Of particular

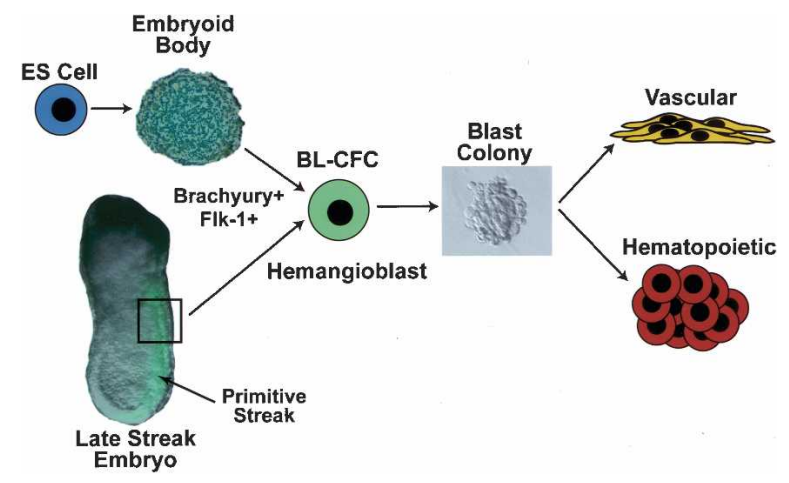

Figure 3. A comparison of BL-CFC development in EBs to hemangioblast development in the early mouse embryo. The EB and embryo are derived from an ES cell line in which the GFP cDNA has been targeted to the brachyury locus (Fehling et al. 2003; Huber et al. 2004). The presence of GFP in the EB and the primitive streak of the embryo is indicative of brachyury expression. interest is the observation that these early hematopoietic cells express markers that are not found on fetal liver and adult hematopoietic populations. Conversely, certain markers associated with fetal and adult hematopoietic cells are absent from embryonic hematopoietic cells. For instance, the earliest hematopoietic populations express the endothelial markers Flk-1 (Kabrun et al. 1997; Nishikawa et al. 1998), and VE-cad (Nishikawa et al. 1998) and the $\alpha \mathrm{IIb}$ (CD41) component of the platelet glycoprotein receptor $\alpha \mathrm{IIb} \beta 3$ (Mitjavila-Garcia et al. 2002; Ferkowicz et al. 2003; Mikkola et al. 2003). These markers are expressed prior to the onset of CD45, a hematopoietic-specific marker present on most fetal liver and adult bone marrow cells. In the fetal liver and adult, Flk-1 (Millauer et al. 1993; Yamaguchi et al. 1993) and VE-cad (Matsuyoshi et al. 1997) are restricted to the endothelial lineage, while CD41 is expressed exclusively in the megakaryocyte lineage (Phillips et al. 1988). The appearance of endothelial markers prior to CD45 has been interpreted by some as evidence that hematopoietic cells develop from a specialized population of endothelial cells, known as hemogenic endothelium. An equally plausible explanation is that the earliest embryonic hematopoietic progenitors that give rise to the later hematopoietic populations express Flk-1 and VE-cad.

With a more detailed understanding of the earliest stages of hematopoiesis, it has been possible to use the ES cell system to begin to investigate the regulation of hematopoietic commitment in a manner that could not be done in the embryo. Findings from such studies have demonstrated that the transcription factors Scl/tal-1 and Runx1 function early in development, specifically at the stage of hematopoietic commitment of the BL-CFC (Faloon et al. 2000; Robertson et al. 2000; Lacaud et al. 2002; D'Souza et al. 2005). With respect to induction and growth regulation, different groups have shown that the development of the BL-CFC and hematopoietic restricted progenitors is positively regulated, directly or indirectly by bFGF (Faloon et al. 2000), VEGF (Nakayama et al. 2000; Park et al. 2004), and Ephrin/Eph (Z. Wang et al. 2004) signaling together with serum-derived factors. Studies conducted in serum-free conditions revealed that BMP4 together with VEGF can support hematopoietic differentiation of ES cells (Nakayama et al. 2000; Park et al. 2004). These factors appear to act at specific developmental stages, with BMP4 functioning to induce Flk- $1^{+}$cells and VEGF playing a role in the generation of Scl/tal-1-expressing hematopoietic and vascular progenitors within this Flk- $1^{+}$population (Park et al. 2004). Molecular analysis revealed that the effects of BMP4 and Flk-1 are mediated through the activation of the SMAD1/5 and MAP kinase pathways, respectively (Park et al. 2004). The findings from these studies are significant as they demonstrate that hematopoiesis can be induced from ES cells with defined factors that are thought to function in a similar fashion in the early embryo. What is not resolved is the role of BMP4 as it could be functioning to induce mesoderm, to specify mesoderm to the hematopoietic program, or both. Further studies using approaches that enable one to monitor the 
earliest stages of germ layer induction will be required to define the precise role of such factors.

In addition to probing early stages of the hematopoietic system, the ES differentiation model offers the potential to generate large numbers of cells from specific hematopoietic lineages for both molecular and biochemical analyses as well as for transplantation for short-term lineage replacement therapy. To date, methods have been established for selectively expanding multipotential cell populations (Pinto do et al. 1998), neutrophils (Lieber et al. 2004), megakaryocytes (Eto et al. 2002), mast cells (Tsai et al. 2000), eosinophils (Hamaguchi-Tsuru et al. 2004), dendritic cells (Fairchild et al. 2003), and definitive erythroid cells (Carotta et al. 2004) from ES cells in culture.

\section{Hematopoietic development from hES cells}

Several studies have documented hematopoietic development in hES cell cultures. Differentiation was achieved by serum induction of cells either through coculture with mouse bone marrow stromal cells (Kaufman et al. 2001) or the generation of EBs (Chadwick et al. 2003; Cerdan et al. 2004). While differentiation was serum-induced, hematopoietic development was augmented in the EBs by the addition to the cultures of BMP4, VEGF, and a mixture of hematopoietic cytokines (Cerdan et al. 2004). Kinetic analysis revealed the development of definitive erythroid and myeloid progenitors following 2 wk of differentiation, a pattern that suggests that hematopoietic induction, under the conditions used, is slower than observed in mouse ES cell differentiation cultures. Distinct primitive and definitive erythroid populations have not yet been identified in the human cultures, although changes in patterns of hemoglobin expression within the ES-cell-derived erythroid lineages have been documented (Cerdan et al. 2004). These changes suggest that at least some aspects of globin switching are taking place, reflecting the changes found during normal fetal development (Stamatoyannopoulos and Grosveld 2001). The hematopoietic potential of hES cells has been recently extended to include the lymphoid lineages, with the observation that cells expressing B-cell markers develop from $\mathrm{CD} 34^{+}$cells following extensive culture on stromal cells (Vodyanik et al. 2005). Analysis of the earliest stages of hematopoietic development in the human system identified a CD45Flk-1 $1^{+}$VE-cad ${ }^{+} \mathrm{CD} 31^{+}$population at day 10 of differentiation that generated $\mathrm{CD} 45^{+}$hematopoietic cells following further culture (L. Wang et al. 2004). These findings suggest that human hematopoietic development within the EBs parallels that of the mouse in that the earliest hematopoietic progenitors express endothelial markers prior to their maturation to $\mathrm{CD} 45^{+}$cells. Together, the findings from this limited number of studies indicate that it is possible to generate hematopoietic cells from hES cells in culture and that the sequence of developmental events may reflect the onset of hematopoiesis in the early embryo.

\section{Vascular development}

The early appearance of the BL-CFC in ES cell differentiation cultures not only defines the onset of hematopoietic commitment, but also represents the earliest stages of vascular development. This pattern of vascular commitment was anticipated, as endothelial cells can be detected early in the yolk sac blood islands of the embryo (Haar and Ackerman 1971). As with the hematopoietic lineages, vascular development appears to be quite efficient in serum-stimulated differentiation cultures (Wang et al. 1992; Bautch et al. 1996; Vittet et al. 1996; Kabrun et al. 1997; Hirashima et al. 1999). Kinetic analysis of endothelial development in intact EBs revealed a sequential up-regulation of the following markers associated with the development and maturation of the lineage; flk-1, CD31, tie2, tie1, and VE-cad (Vittet et al. 1996). This pattern is similar to that observed in the early embryo, suggesting that development of the endothelial lineage in vitro recapitulates its development in vivo. A similar pattern of differentiation was observed when Flk- $1^{+}$progenitors were isolated from the differentiation cultures and recultured on type IV collagen-coated dishes or on OP9 stromal cells (Hirashima et al. 1999). Further analysis of this ES-cell-derived Flk-1 population revealed that it also displayed the capacity to generate cells of the VSM lineage. Clonal analysis demonstrated that both the endothelial and VSM lineages develop from a common progenitor, a cell that can be considered to be a vascular progenitor (Yamashita et al. 2000). A comparable progenitor was also identified in the yolk sac of the embryo. These findings are important as they define a new branch point within the vascular system and, in doing so, further highlight the power of the ES cell system in studying early lineage commitment.

Studies on the regulation of vascular commitment have revealed that factors essential for the development and maturation of the endothelial lineage in the early embryo, including VEGF (Carmeliet et al. 1996; Ferrara et al. 1996) and the receptors Flt1 (Fong et al. 1995) and Flk-1 (Shalaby et al. 1995), are also required for the establishment of the lineage in ES cell differentiation cultures (Bautch et al. 2000; Kearney et al. 2002; Zippo et al. 2004). The regulation of endothelial and VSM development in ES cell cultures is also controlled, in part, by the transcription factor Scl/tal-1. In the absence of Scl/tal-1, ES cells favor the VSM pathway, while when expressed, they differentiate to both the endothelial and VSM lineages (Ema et al. 2003; D'Souza et al. 2005).

The functional capacity of the ES-cell-derived vascular progenitors has been evaluated both in culture and in animal models following transplantation. ES-cellderived vascular cells are able to organize into vessel-like structures in EBs (Doetschman et al. 1985), in explant cultures (Bautch et al. 1996), or when cultured on collagen I (Yamashita et al. 2000). When transplanted into tumor-bearing mice, ES-cell-derived progenitors incorporated into the newly formed vessel in the tumors, indicating that they can function as vascular cells and participate in neovascularization in vivo (Marchetti et al. 
2002; Yurugi-Kobayashi et al. 2003). These observations are significant as they demonstrate that the ES cell differentiation system can be used as a model for investigating the mechanisms regulating angiogenesis in tumor formation.

Endothelial differentiation has also been demonstrated in hES cell differentiation cultures (Levenberg et al. 2002). The cells that develop in these cultures express markers associated with the endothelial lineage, form tube-like structures in matrigel in vitro, and generate capillary structures when embedded in sponges and transplanted into SCID mice. Taken together, the findings from studies on vascular development of ES cells demonstrate that the lineages develop efficiently and that the cells that are generated display properties of normal endothelial and VSM cells.

\section{Cardiac development}

The development of the cardiac lineage in ES cell differentiation cultures is easily detected by the appearance of areas of contracting cells that display characteristics of cardiomyocytes. Development of the cardiomyocyte lineage has been analyzed in most detail in cultures induced with serum (Hescheler et al. 1997; Boheler et al. 2002). As observed with the hematopoietic and vascular systems, development of the cardiomyocyte lineage progresses through distinct stages that are similar to development of the lineage in vivo. An ordered pattern of expression of cardiac genes is observed in the differentiation cultures, with expression of the transcription factors gata-4 and $n k x 2.5$ that are required for lineage development preceding the expression of genes such as atrial natriuretic protein $(A N P)$, myosin light chain $(M L C)-2 v, \alpha$-myosin heavy chain $(\alpha-M H C), \beta$-myosin heavy chain $(\beta-M H C)$, and connexin 43 that are indicative of distinct maturation stages within the developing organ in vivo (Hescheler et al. 1997; Boheler et al. 2002). Maturation of the lineage in the cultures is associated with changes in cell size and shape, progressing from small, round cells to elongated cells with well-developed myofibrils and sarcomeres (Boheler et al. 2002). Electrophysiologicial measurements of cells from different times in culture suggest that the cardiomyocyte population undergoes a change from early-stage cells with pacemaker-like activity to more terminally differentiated atrial- and ventricular-like cells (Maltsev et al. 1993; Hescheler et al. 1997; Banach et al. 2003). These changes correlate with the observed changes in cellular morphology, characteristic of each cell type.

While these studies clearly demonstrate the development of the cardiomyocyte lineage from differentiating ES cells, they are carried out in heterogeneous cultures in which these cells represent a minority of the entire population (Klug et al. 1996). As there are relatively few antibodies available for the isolation of cardiac progenitors, investigators have genetically engineered ES cells to enable specific selection of cells representing different stages of development within the lineage. ES cells have been generated to express either drug-resistance or fluo- rescent genes under the control of promoters that drive expression at specific stages of cardiac development. In the first of these approaches, Klug et al. (1996) expressed the neomycin-resistance gene under the control of the $\alpha$-cardiac MHC promoter. With G418 selection at appropriate stages of development, populations highly enriched $(>99 \%)$ for cardiomyocytes were isolated. When applied to large-scale cultures, this strategy enabled the generation of large numbers of cardiomyocytes (Zandstra et al. 2003). Other strategies involve expressing the green fluorescent protein (GFP) from cardiac specific promoters including Nkx2.5 (Hidaka et al. 2003), cardiac $\alpha$-actin (Kolossov et al. 1998), and myosin light chain-2v (Muller et al. 2000). Expression from myosin light chain-2v was designed to specifically select for ventricular cells from the ES cell differentiation cultures (Muller et al. 2000). Cells selected on this basis displayed electrophysiological properties of ventricular cardiomyocytes, indicating that the strategy was successful.

Several different studies have begun to investigate the mechanisms regulating the development of the cardiac lineage in ES cell differentiation cultures. Parisi et al. (2003) demonstrated that the EGF-CFC factor Cripto, known to be essential for cardiomyocyte development in vivo (Ding et al. 1998), plays a pivotal role in differentiation of ES cells to the cardiac lineage. Cripto $^{-/}$ES cells display a deficiency in generating cardiomyocytes in culture that could be restored by the addition of soluble Cripto to the differentiation cultures. Of interest was the observation that the factor had to be supplied within the first $48 \mathrm{~h}$ of differentiation, suggesting that its primary function may be on the induction of mesoderm, which, in turn, differentiates to the cardiac lineage. Notch signaling also plays a role in cardiac development from ES cells (Schroeder et al. 2003). However, in this case, inhibition of the pathway appears to be important for cardiac differentiation, as ES cells lacking the recombination signal sequence-binding protein $\mathrm{Jk}$, a downstream signaling molecule of all Notch receptors, generate more cardiac cells than wild-type ES cells. Other factors, including BMP2 and FGF2 (Kawai et al. 2004) as well as nitric oxide (Kanno et al. 2004) and ascorbic acid (Takahashi et al. 2003), have been shown to promote or improve cardiomyocyte differentiation in ES cell cultures. As observed with Cripto, the effects of BMP-2 and FGF were most dramatic when the factors were added early in the differentiation cultures, again suggesting that some of the effects may be mediated at the level of mesoderm induction. A role for FGF signaling in ES-cell-derived cardiac development is further supported by the observation that gfr $1^{-1-}$ ES cells show a marked defect in their ability to differentiate to cardiomyocytes (Dell'Era et al. 2003). Factors produced by visceral endoderm also appear to play a role in cardiomyocyte differentiation as coculture of ES cells with a visceral endoderm-like cell line, END2, significantly enhanced cardiac development (Mummery et al. 2002). The nature of the END-2-derived molecules responsible for cardiac development remains to be determined.

While these studies have identified several factors that 
regulate cardiac development from ES cells, the precise stage at which they act and their relationship to each other remain to be elucidated. To characterize the mechanisms regulating cardiac development in the ES cell differentiation cultures in more detail, it will be necessary to use approaches that enable one to monitor and isolate the earliest stages of development within this lineage.

\section{Transplantation of ES-cell-derived cardiomyocytes}

One of the most promising applications of cardiomyocyte differentiation of ES cells is to provide a source of transplantable cells for the treatment of cardiovascular disease (Kehat and Gepstein 2003; Nir et al. 2003). Klug et al. (1996) first demonstrated that ES-cell-derived cardiomyocytes selected for $\alpha$-cardiac MHC expression could incorporate and survive in the hearts of dystrophic mice, following direct transplantation into the organ. More recent studies have demonstrated that mouse EScell-derived cells can survive for up to $32 \mathrm{wk}$ following transplantation into the hearts of rats with myocardial infarction (Min et al. 2002, 2003). For these studies, areas of contracting cardiac cells were dissected from heterogeneous differentiation cultures and used for transplantation. Analysis of the animals indicated improved cardiac function in those transplanted with the ES-cell-derived cells compared to controls that received cell-free media. Histological analysis demonstrated the presence of differentiated donor-derived cardiac cells. To improve the survival of the ES-cell-derived cardiomyocytes, Yang et al. (2002), engineered the expression of VEGF in the cardiomyocytes prior to transplantation into the hearts of mice that had suffered myocardial infarction. Mice that received the VEGF-expressing cells displayed enhanced neovascularization and improved cardiac function compared with animals transplanted with wild-type cells.

Although the findings from these studies are encouraging, it is unclear to what extent the improvement is due to the myocyte function of the cells rather than to indirect effects such as induced vascular development at the site of injection. Future studies need to include the injection of noncardiac cells to control for the cardiac lineage specificity of the observed improvement. An additional issue relates to the differentiation status of transplanted cells. In the studies described above, relatively mature contracting cardiomyocytes were transplanted. It is conceivable that populations consisting of immature progenitor cells may be more effective in repair of the damaged heart, as such cells should display greater proliferative potential than the contracting cells and thus generate a larger graft. Identification and characterization of early-stage cardiac progenitors in ES cell differentiation cultures are important goals for the future.

\section{Cardiac development from hES cells}

Cardiomyocyte differentiation has also been demonstrated in hES cell differentiation cultures (Nir et al.
2003). As observed with the mouse system, the cells differentiate over time in culture, following a maturation process similar to that reported in vivo (Kehat et al. 2001; Nir et al. 2003; Snir et al. 2003). Although the hES-cellderived cardiomyocytes do not undergo maturation to the stage of adult cardiomyocytes, cells with electrical properties of nodal, atrial, and ventricular cells have been identified (He et al. 2003). The induction events for cardiac development in the hES cell cultures have not been defined in any detail, and in most studies the populations are generated following serum stimulation. As observed with mouse ES cells, coculture of hES cells with END-2 endoderm cells enhanced the development of cardiac cells in these differentiation cultures (Mummery et al. 2003).

Recently, hES-cell-derived cardiomyocytes have been used in xenogeneic transplantation as "biologic pacemakers" for the treatment of bradycardia (Kehat et al. 2004). To demonstrate this potential, clusters of contracting cardiomyocytes isolated from the differentiation cultures were transplanted into the left ventricle of pigs that had their atrioventricular node ablated. The recipient hearts had spontaneous rhythms that appeared to originate from the transplanted cells as assessed by highresolution electroanatomical mapping. Though promising, these results also raise the concern that transplanted cells could serve as a nidus for arrhythmia.

\section{Other mesoderm-derived lineages}

While the hematopoietic, vascular, and cardiac lineages have been studied in most detail, the ES cell system does offer the potential to develop many other mesoderm lineages. To date, cell populations representing the skeletal muscle (Rohwedel et al. 1994), the osteogenic (Buttery et al. 2001; zur Nieden et al. 2003), the chrondrogenic (Kramer et al. 2000), and adipogenic (Dani et al. 1997) lineages have been generated from ES cells differentiated in culture. Where analyzed in detail, the development of the lineage in vitro recapitulated its development in vivo, indicating that these populations progressed through normal differentiation programs. As with the other lineages discussed in this review, access to these cell types from ES cells offer unprecedented opportunities to establish model systems to study lineage commitment and to provide a source of cells for transplantation.

\section{Endoderm derivatives}

The generation of endoderm derivatives, in particular pancreatic $\beta$-cells and hepatocytes, has become the focus of many investigators in the field of ES cell biology. The interest in the efficient and reproducible development of these cell types derives from their clinical potential for the treatment of Type I diabetes and liver disease, respectively. Despite the interest in these lineages, progress in generating endoderm-derived cell types has been slow. The lack of progress in this area can be attributed to 
several different factors. First, several genes used as markers of definitive endoderm (Foxa2, Gata4, and Sox17) (Arceci et al. 1993; Monaghan et al. 1993; Sasaki and Hogan 1993; Laverriere et al. 1994; Kanai-Azuma et al. 2002), early liver ( $\alpha$-fetoprotein and albumin) (Dziadek and Adamson 1978; Meehan et al. 1984; Sellem et al. 1984), and early pancreas ( $P d x 1$ and insulin) (McGrath and Palis 1997) development are also expressed by visceral endoderm. Visceral endoderm, a population of extraembyonic endoderm, is an extraembryonic tissue that functions in a regulatory capacity but does not contribute directly to the formation of any adult organs (Fig. 1; Gardner and Rossant 1979; Thomas and Beddington 1996). Given the overlapping expression patterns, it can be difficult to distinguish definitive and extraembryonic endoderm in the ES cell differentiation cultures.

While ES cells do not contribute extensively to visceral endoderm in vivo following injection into blastocysts (Beddington and Robertson 1989), they do display some capacity to generate this population in culture (Doetschman et al. 1985; Soudais et al. 1995). The transcription factors nanog, GATA-4, and GATA-6 all appear to play some role in the regulation of visceral endoderm development from ES cells. ES cells lacking nanog (Mitsui et al. 2003) or those engineered to overexpress GATA-4 or GATA-6 (Fujikura et al. 2002) differentiate to visceral endoderm in the presence of LIF. Recently, Hamazaki et al. (2004) demonstrated that aggregation of ES cells in the presence of LIF is sufficient to downregulate nanog expression and induce visceral endoderm development. With hES cell cultures, BMP2 has been shown to induce cells with visceral endoderm characteristics (Pera et al. 2004). The fact that ES cells can generate visceral endoderm in culture makes it imperative that one establish appropriate strategies for identifying definitive endoderm and its derivatives. Approaches to address this issue could include the identification of genes that are differentially expressed between the endoderm populations and the establishment of conditions that specifically support the development of definitive endoderm.

A second problem encountered in endoderm differentiation from ES cells is the lack of specific inducers of this lineage. In most studies to date, endoderm development has been analyzed in ES cell cultures differentiated in the presence of FCS. While FCS appears to efficiently induce mesoderm populations, particularly the hematopoietic, vascular, and cardiac lineages, findings from a recent study demonstrate that it is not the optimal inducer of endoderm (Kubo et al. 2004).

In spite of these obstacles, several studies have provided evidence for the generation of endoderm-derived cell types including populations that display characteristics of pancreatic islets (Colman 2004; Stoffel et al. 2004), hepatocytes (Hamazaki et al. 2001; Jones et al. 2002; Yamada et al. 2002a), thyrocytes (Lin et al. 2003), lung (Ali et al. 2002), and intestinal cells (Yamada et al. $2002 \mathrm{~b}$ ). This review focuses on pancreatic and hepatocyte development.

\section{Pancreatic development from ES cells}

Two general protocols have been used for the generation of pancreatic islet-like cells from ES cells in culture. The first, a five-step protocol, described by Lumelsky et al. (2001), is an adaptation of a protocol for neural cell differentiation and involves the transfer of serum-induced EBs to serum-free medium followed by treatment with FGF and factors that promote maturation of endocrine cells. Clusters resembling pancreatic islets developed in these cultures and cells within the clusters were shown to contain insulin, glucagon, or somatostatin by immunohistochemistry. While the insulin content of the cells was low, they were able to secrete insulin in response to glucose. However, when tested for their ability to function in vivo following transplantation into streptozotocin (STZ)-induced diabetic mice, these cells failed to correct the hyperglycemia of these animals. The inability to "cure" these animals could be due to the fact that the cells were too immature or that they were not islet cells.

Several other groups have modified this approach and reported improved development of $\beta$-like cells in the cultures. The modifications included constitutive expression of the transcription factor Pax4 (Blyszczuk et al. 2003) during differentiation, inducible expression of $P d x 1$ (Miyazaki et al. 2004) during differentiation, or exposure of the cells to the inhibitor of phosphoinositide 3-kinase (PI3K), LY294002 (Hori et al. 2002), at the final maturation step. $P d x 1$ and $P a x 4$ are essential for $\beta$-cell development in vivo (Murtaugh and Melton 2003). Transplantation of the Pax4-induced and LY294002treated cells into STZ-treated recipients did improve the hyperglycemia in these animals, suggesting that ESderived cells were producing insulin. Of significance was the observation that removal of the LY294002-treated graft resulted in reversion to a diabetic state, indicating that the observed improvement was due to the implanted cells. While these findings are encouraging, several issues remain to be resolved regarding the types of cells generated and the amount and type of insulin produced in these cultures.

Rodents contain two nonallelic insulin genes, insulin I and insulin II (Melloul et al. 2002). While insulin I is expressed predominantly in $\beta$-cells, insulin II is found in the yolk sac and developing brain in addition to the pancreas (Deltour et al. 1993; Devaskar et al. 1993; Giddings et al. 1994). Given that the ES cell cultures described above do contain significant numbers of neuronal cells, it is possible that some of the insulin detected is derived from these cells, as demonstrated by the recent study of Sipione et al. (2004). A second issue relates to the observation that ES-cell-derived cells can absorb insulin from the tissue culture medium and then release it when stressed or undergoing apoptosis (Rajagopal et al. 2003). It is unclear to what extent neuronal-derived insulin or the release of absorbed insulin is involved in the above studies as the cultures contain mixed populations of cells. Resolution of these issues and the development of large numbers of functional insulin-producing cells will 
require improved protocols for endoderm induction and $\beta$-cell specification and maturation.

Some of the concerns relating to $\beta$-cell development in ES cell cultures were addressed in a recent study of $\mathrm{Ku}$ et al. (2004). In this work, modification of the components of the serum-free culture and maturation of the differentiating cells in the presence of activin $\beta B$, exendin-4, and nicotinamide, resulted in the development of cell populations that expressed insulin I, following the appearance of cells that expressed various genes indicative of endoderm differentiation. Immunostaining revealed that cells within the cultures also contained c-peptide, the cleavage by-product of proinsulin, indicating that at least some of the insulin detected is produced by the cells. The modification to the maturation cultures significantly increased the levels of insulin I mRNA as well as the frequency of cells that express insulin (to $2 \%-3 \%$ of the total) in the population. These findings are encouraging and offer hope that further modifications together with selection approaches will yield populations highly enriched for $\beta$-cells.

A second approach for the generation of islet-like structures relies on their development in heterogeneous populations derived from ES cells following serum induction. Such approaches have yielded, at a low frequency, cells that display many characteristics of $\beta$-cells, including the presence of c-peptide and insulin in discrete granules within the cells (Kahan et al. 2003). To enrich for $\beta$-cells from heterogeneous serum-induced cultures, Soria et al. (2000) developed a selection strategy based on the insulin promoter driving expression of the selectable gene $\beta$-geo. Addition of G418 to the cultures resulted in the isolation of an insulin-secreting clone that had insulin contents similar to that of normal islets. When injected into STZ diabetic mice, these cells corrected the hyperglycemia of these animals for up to 12 wk. Beyond this time, however, a significant number of animals reverted back to a hyperglycemic stage, indicating that the cells were unable to provide long-term $\beta$-cell function.

As a strategy to select for early pancreatic cells as they develop in ES cell differentiation cultures, Micallef et al. (2005) targeted GFP to the $p d x 1$ locus. $P d x 1$ is expressed in the earliest stages of pancreatic development as the organ rudiments are specified from the gut endoderm (Murtaugh and Melton 2003). Treatment of the developing EBs with retinoic acid in this study led to the development of a small GFP-pdx1 $1^{+}$population by day 8 of differentiation. Analysis of the isolated GFP-pdx $1^{+}$cells revealed that they expressed endoderm-specific genes but not genes associated with pancreatic maturation, suggesting that they represent an early stage of endoderm development. Alternatively, some of the cells within the population could be visceral endoderm, a tissue that also expresses $p d x 1$ (McGrath and Palis 1997). Further studies will be required to demonstrate that this population does represent the earliest stages of pancreatic differentiation. The generation of the $\mathrm{pdx} 1$ selectable marker is a good strategy that will enable the quan- titation and isolation of pancreatic lineage progenitors from cultures induced under optimal conditions for definitive endoderm development.

Insulin-expressing cells have also been detected in hES cell differentiation cultures (Assady et al. 2001). However, as with many of the studies with mouse cells, the frequency of these cells in the hES cell cultures is currently too low to allow detailed characterization and functional analysis.

\section{Hepatocyte development from ES cells}

Several reports have documented the generation of cells with hepatocyte characteristics in ES cell differentiation cultures. Hamazaki et al. (2001) developed a multistep protocol that included the addition of specific growth factors at various stages of differentiation to promote the growth and differentiation of hepatocyte cells within the cultures. Genes indicative of hepatocyte development and maturation were expressed in these cultures with a kinetic pattern similar to that found in vivo. Hepatocytelike cells generated with this protocol were subsequently shown to contain albumin protein and to produce urea (Chinzei et al. 2002). Cells from these cultures were also transplanted into recipient mice pretreated with 2-acetylaminofluorene to prevent proliferation of host hepatocytes. Four weeks following transplantation, low numbers of albumin-producing donor cells were detected in the livers of the recipient animals, suggesting that these cells might be able to function in vivo (Chinzei et al. 2002).

To be able to specifically monitor hepatocyte development and isolate these cells from the differentiation cultures, several studies have incorporated approaches to distinguish definitive endoderm and early liver populations from visceral endoderm. Jones et al. (2002) used an ES cell line carrying a lacZ gene trap vector inserted into a gene known as Gtar. Gtar is expressed in definitive endoderm committed to a hepatic fate and the developing liver but is not found in visceral endoderm. Following serum induction, LacZ-positive cells that coexpressed $\alpha$-fetoprotein (afp) and albumin (alb) were detected, indicating development of the hepatocyte lineage in the culture. In a recent study, Asahina et al. (2004) identified cytochrome P450 7A1 (Cyp7a1) as a liver-specific gene that is not expressed in visceral endoderm. Cyp7a1 expression was detected at low levels in serumstimulated EBs at 2 wk of differentiation. As the Cyp 7a1positive cells were not isolated or characterized in this study, their developmental potential remains to be determined. Yamada et al. (2002a) used specific uptake of the organic anion indocyanine green (ICG) as a marker of hepatocyte development in ES differentiation cultures. ICG-positive cells isolated from the cultures expressed hepatocyte markers, displayed ultrastructural characteristics similar to those of hepatocytes and gave rise to low numbers of albumin-positive cells following transplantation into recipient animals. Taken together, the findings from these various studies strongly suggest that 
cells with hepatocyte characteristics are generated in mouse ES cell differentiation cultures.

Cells with hepatocyte characteristics have also been identified in hES cell cultures (Rambhatla et al. 2003). To generate these cells, the cultures were treated with sodium butyrate, a procedure that killed significant numbers of the differentiating population. The cells that survived this treatment gave rise to a population that displayed many features of hepatocytes. Although the approach is promising and results in the development of hepatocyte-like cells, the physiological relevance of the sodium butyrate treatment is unclear.

The findings from these different studies indicate that cells with characteristics of pancreatic $\beta$-cells and hepatocytes can be generated in ES cell differentiation cultures. A problem with many of the current approaches is the very low frequency of differentiated cells identified and the cellular heterogeneity within the cultures. Improvements in generating endoderm derivatives will require the development of more efficient protocols for endoderm induction and for pancreatic and hepatocyte specification combined with technologies for selecting the appropriate cell types from the differentiation cultures. Only when large numbers of highly enriched progenitors are accessible can methods for their maturation be defined and their functional capacity be rigorously tested in animal models of diabetes and liver failure.

We have recently investigated the potential of ES cells to differentiate to endoderm derivatives and developed two different protocols that promote the generation of these cell types (Kubo et al. 2004). The first is a restricted exposure of the EBs to serum followed by a period of serum-free culture, and the second is induction with activin A (activin) in the absence of serum. Endoderm development was quantified based on the proportion of cells that expressed Foxa2, a transcription factor found in the earliest stages of definitive endoderm development (Monaghan et al. 1993; Sasaki and Hogan 1993). All of the Foxa2 ${ }^{+}$cells that developed in these cultures also expressed the primitive streak marker brachyury, a gene that is not expressed in visceral endoderm. This observation strongly suggests that the Foxa $2^{+}$cells represented definitive endoderm. Based on the number of Foxa2 $2^{+}$cells, the activin protocol was found to be the most efficient as $>50 \%$ of the total population in these cultures expressed this protein. Tissue specification was detected in the activin-induced cultures as demonstrated by the presence of cells that expressed $A f p$ and $A l b$, indicative of hepatocyte differentiation, $P d x 1$ for early pancreas specification, and surfactant protein C $(S p-c)$ for early lung development (Wert et al. 1993). When transplanted under the kidney capsule of recipient mice, the activin-induced cells generated lunglike structures that expressed $S p-c$ and gut structures that expressed intestinal fatty acid-binding protein (IFABP). These findings demonstrate that it is possible to efficiently generate endoderm in ES differentiation cultures with the use of specific inducers in the absence of serum.

\section{Ectoderm derivatives}

Ectoderm differentiation of mouse ES cells is well established, as numerous studies have documented and characterized neuroectoderm commitment and neural differentiation. Given extensive efforts in this field over the past decade, several different protocols have evolved to promote neuroectoderm differentiation. The various approaches include (1) treatment of serum-stimulated EBs with retinoic acid (Bain et al. 1995), (2) sequential culture of EBs in serum followed by serum-free medium /Okabe et al. 1996), (3) differentiation of ES cells as a monolayer in serum-free medium (Tropepe et al. 2001; Ying et al. $2003 b$ ), and (4) differentiation of ES cells directly on stromal cells in the absence of serum (Kawasaki et al. 2000; Barberi et al. 2003). As with the mesoderm and endoderm lineages, development of the ectoderm lineages in the ES differentiation cultures appears to recapitulate their development in the early embryo (Barberi et al. 2003). Commitment to neuroectoderm appears to be rapid and efficient as the majority of the cells that develop in these cultures display characteristics of neural cells (Okabe et al. 1996; Kawasaki et al. 2000; Barberi et al. 2003). By targeting the $\beta$-geo selection marker gene to Sox2, a gene expressed in neuroepithelium, Li et al. (1998) were able to generate highly enriched neural populations ( $>90 \%$ of the population) using the retinoic acidinduction protocol followed by selection with G418.

Each of the three major neural cell types of the central nervous system-neurons, astrocytes, and oligodendrocytes-can be generated, and relatively pure populations of each can be isolated when cultured under appropriate conditions (Okabe et al. 1996; Barberi et al. 2003). In addition to the generation of these different neural populations, conditions have been established for the development of different subtypes of neurons. The protocols for differentiation to specific types of neurons have included the sequential combination of regulators that are known to play a role in the establishment of these lineages in the early embryo. For instance, midbrain dopaminergic neurons have been generated in the EB system by overexpression in the cells of the transcription factor nuclear-receptor-related factorl (Nurr1), and the addition to the cultures of SHH and FGF8 (Kim et al. 2002). Nurr1, SHH, and FGF8 are required for the development of this class of neurons in the early embryo (Ye et al. 1998; Simon et al. 2003). More recent studies have demonstrated the development of cholinergic, serotonergic, and GABAergic neurons in addition to dopaminergic neurons, when differentiated on MS5 stromal cells in the presence of different combinations of cytokines (Barberi et al. 2003). Using the coculture approach together with the appropriate signaling molecules and selection steps, Wichterle et al. (2002) successfully generated cells that display many of the characteristics of motor neurons. As with many other populations discussed in this review, the generation of these cells from ES cells recapitulated the pathway of motor neuron development in vivo.

The ES cell model is being used to investigate the earliest stages of neural development. When cultured at low 
density in serum-free medium in the presence of LIF, ES cells generate a population that has been called primitive neural stem cells (Tropepe et al. 2001). These cells have been characterized by their ability to generate neurosphere-like colonies composed of cells that express the neural precursor cell marker, nestin (Lendahl et al. 1990). When cultured on a matrigel substrate in the presence of low amounts of serum, cells within these colonies generated neurons, astrocytes, and oligodendrocytes. Mesoderm and definitive endoderm derivatives were not detected in these cultures. In contrast to the restricted developmental pattern observed in culture, the cells from these colonies were able to contribute to most tissues of the embryo following morula reaggregation and transplantation in vivo. These observations would position the primitive neural stem cell at a developmental stage between the ES cell and a neural-restricted progenitor.

The ability to generate different types of neurons from ES cells has dramatically raised the interest in repair of nervous system disorders by cell replacement therapy. Early transplantation studies demonstrated the feasibility of engrafting ES-cell-derived neural cells into recipient animals. Brustle et al. (1997) transplanted such cells into ventricles of fetal rats and demonstrated the incorporation of donor-derived neurons, astrocytes, and oligodendrocytes into the brains of the recipient animals, several weeks later. As a demonstration of cell-based repair, this group showed that ES-cell-derived oligodendrocytes could form myelin sheaths around host neurons when transplanted into a myelin-deficient rat model of multiple sclerosis (Brustle et al. 1999). Other studies demonstrated that ES-cell-derived neural cells could lead to partial functional recovery of spinal cord injury in rats, when injected directly into the spinal cord near the injury site (McDonald et al. 1999). Although the basis for recovery in this study was not determined, remyelination of the damaged nerves may have played some role, as a later study demonstrated that ES-cell-derived neural cells transplanted into spinal cords of rats with chemically induced demyelination preferentially differentiate into oligoendrocytes and myelinated host axons (Liu et al. 2000).

One of the greatest expectations of clinical utility for ES-cell-based therapy for neurodegenerative disease is the replacement of dopamine neurons in Parkinson's patients. Using a rat model for Parkinson's disease, Kim et al. (2002) demonstrated that ES-cell-derived dopamine neurons survived, developed functional synapses, and displayed electrophysiolgic properties characteristic of midbrain neurons following transplantation into these animals. In addition, the animals showed some recovery, suggesting that the transplanted cells were functional. The animals that received cells overexpressing Nurrl showed the greatest improvement in this study. Populations not overexpressing exogenous Nurrl generated with the stromal cell coculture protocol have also been transplanted into Parkinsonian mice (Barberi et al. 2003). Donor dopamine neurons were detected 2 mo following transplantation, and grafted animals showed alleviation of the behavioral deficits displayed by the control animals. Taken together, these studies establish that it is possible to generate specific subsets of neural cells from mouse ES cells and that these cells can be transplanted into models of human diseases. Additional studies will be required to determine the extent to which these cells can function over extended periods of time.

In addition to the neural lineages, ES cells can also give rise to epithelial cells that will undergo differentiation to populations that express markers of keratinocytes (Bagutti et al. 1996). The temporal sequence of expression of different keratins associated with development of the lineage in culture is very similar to patterns found in the mouse embryo. When maintained for $3 \mathrm{wk}$ in organ cultures, the ES-cell-derived keratinocytes were able to form structures that resemble embryonic mouse skin, indicating that they possess some capacity to generate a functional tissue (Coraux et al. 2003). Differentiation of the epidermal cells appears to be controlled, in part, by BMP4 (Kawasaki et al. 2000). When added to cultures undergoing neuroectoderm differentiation, BMP4 promoted keratinocyte development and inhibited neural differentiation.

\section{Neural development from hES cells}

Ectoderm derivatives have also been generated from hES cells and as with the mouse, most studies have focused on neuroectoderm and neural cells (Hornstein and Benvenisty 2004). The three CNS cell types can be derived from hES cells using several different protocols (Reubinoff et al. 2001; Zhang et al. 2001). When transplanted into newborn mice, hES-cell-derived neural cells generated neurons and glia that could be detected in different regions of the recipient brain 4 wk later (Zhang et al. 2001). Morphological analysis indicated that the donor cells had matured and were indistinguishable from the surrounding host cells. As observed with the mouse cells, coculture of hES cells with stromal cells led to the development of neural populations with midbrain dopamine characteristics (Perrier et al. 2004; Zeng et al. 2004). Cell populations displaying varying degrees of dopaminergic neuron differentiation have been transplanted into Parkinsonian rats (Ben-Hur et al. 2004; Zeng et al. 2004). Low numbers of human cells could be detected in the animals between 5 and 12 wk post-transplantation, and improvements in the behavior of some of the transplanted animals were noted in one of the studies (Ben-Hur et al. 2004). However, given that the graft that these animals received consisted of a mixture of neural and nonneural cells and that very few dopaminergic cells were detected in the recipients, the significance of these improvements is unclear. Future studies in which highly enriched populations of appropriate staged dopaminergic neurons are transplanted into a variety of different models will be required to determine the potential of this approach as a treatment of Parkinson's disease. 


\section{Germ cells}

In addition to somatic tissues, several studies have documented the development of germ cells from differentiated ES cells. In the first study, ES cells were induced to differentiate in two-dimensional cultures in the presence of serum without additional factors (Hubner et al. 2003). To identify the developing germ cells in the differentiation cultures, the ES cells carried a modified Oct 4 promoter that drove GFP expression specifically in the germline. GFP expression was detected as early as day 4 of differentiation, and by day 8 up to $40 \%$ of the population was positive. By day 26 of culture, oocyte-like cells enclosed in a structure resembling a zona pellucida were released into the culture from the differentiating cell mass. Following several additional weeks of culture, structures similar to blastocysts were observed, likely originating from the parthenogenic activation of the oocytes.

Male germ cell development has also been demonstrated in ES cell differentiation cultures. With one approach, developing germ cells were identified using an ES cell line in which GFP was targeted to the mouse vasa homolog $(M v h)$, a gene specifically expressed in germline cells (Toyooka et al. 2003). While $\mathrm{GFP}^{+}$cells were detected in EBs stimulated with serum alone, the number was significantly enhanced when the EBs were coaggregated with a BMP4-expressing cell line. This observation is encouraging as BMP4 is a known regulator of germ cell development in the mouse embryo (Lawson et al. 1999). To determine the potential of these putative germ cells, $\mathrm{GFP}^{+}$cells were isolated from the EBs, cocultured with gonadal cells, and then transplanted under a host testis capsule, where they were shown to participate in spermatogenesis. In the second study, germ cells generated in serum-stimulated EBs were isolated on the basis of SSEA1 expression and cultured in the presence of retinoic acid, LIF, bFGF, and c-kit ligand (Geijsen et al. 2004). Cells differentiated under these conditions displayed imprint erasure, a distinguishing characteristic of germ cells. If maintained in culture for $2 \mathrm{wk}$, these serum-stimulated EBs generated a small population of spermatid-like cells that could be isolated using an antibody recognizing the sperm acrosome. This population was enriched for haploid cells that were able to complete fertilization, following injection into oocytes.

Germ cell development has also been analyzed in hES cell differentiation cultures (Clark et al. 2004). In this study, gene expression profiles suggested the development of both male and female germ cells in serumstimulated EBs. However, as the cells were not isolated and further characterized, the efficiency of differentiation and the extent of lineage maturation are unknown.

The findings from these different studies clearly demonstrate that it is possible to generate germ cells from mouse ES cells and, in doing so, open new and exciting avenues for researchers to study the development of this lineage. Before the model can be widely used for such studies, however, it will be important to define the regulators that induce germ cell development, preferably in the absence of serum. With appropriate conditions, it should be possible to reproducibly generate large numbers of such cells.

The studies reviewed in the previous sections indicate that it is possible to generate derivatives of the three primary germ layers as well as germ cells from ES cells differentiated in culture. They also highlight the fact that the efficiency in forming different cell types varies considerably as neuroectoderm and certain mesoderm derivatives including the hematopoietic, vascular, and cardiac lineages are reasonably easy to generate, whereas the development of definitive endoderm and its derivatives such as mature hepatocytes and pancreatic $\beta$-cells are considerably more challenging. Given the complexity of lineage development in the early embryo, it is remarkable that it is possible to generate any mature populations in a reproducible manner from differentiated ES cells. While the successes to date highlight the importance and potential of this model system, significant improvements in lineage development, in particular endoderm and its derivative populations, will ultimately depend on gaining a better understanding of the events regulating the induction of the primary germ layers. To achieve this, it will be important to recapitulate the developmental events of the early embryo in the ES cell system, to use serum-free conditions and defined molecules for differentiation, and to develop reporter systems that enable one to quantify lineage development.

\section{Development of the embryo: generation of the earliest cell populations}

Early in mouse embryo development, the inner cell mass proliferates rapidly and differentiates to generate a population of pluripotent cells known as primitive ectoderm. Shortly after implantation, the innermost cells of the primitive ectoderm cell mass undergo apoptosis and form a cavity through a process known as cavitation (Coucouvanis and Martin 1995). The surviving primitive ectoderm cells that surround the cavity differentiate to form a pseudostratified columnar epithelium, giving rise to a structure known as the epiblast (Fig. 4). Although they retain pluripotentiality, primitive ectoderm/epiblast cells can be distinguished from the inner cell mass on a morphological basis, by the fact that they have upregulated $f g f 5$ expression (Haub and Goldfarb 1991; Hebert et al. 1991) and down-regulated rex1 expression (Rogers et al. 1991), and by the fact that they can no longer contribute to chimera formation following blastocyst injection (Rossant 1977; Beddington 1983). The epiblast responds to extrinsic signals and gives rise to the primary germ layers (Gardner and Rossant 1979) as well as the primordial germ cells (Ginsburg et al. 1990).

The primary germ layers in the embryo are formed during the process of gastrulation, which begins at approximately embryonic day 6.5 (E6.5) in the mouse (Tam and Behringer 1997). At the onset of gastrulation, the epiblast cells in the region that will define the posterior part of the embryo thicken and form a transient structure known as the primitive streak (Fig. 4). During gas- 


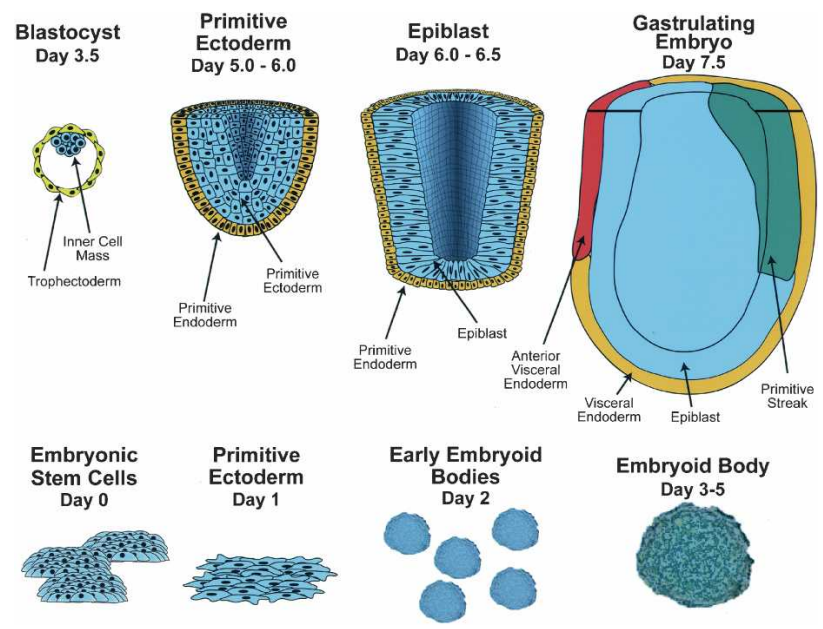

Figure 4. A model comparing the early stages of embryonic and ES/EB development. The green-colored populations in the gastrulating embryo and the day 3 EBs are indicative of brachyury expression.

trulation, epiblast cells traverse the primitive streak and undergo an epithelial to mesenchymal transition, giving rise to mesoderm and definitive endoderm. Fate-mapping studies have demonstrated that the development of subpopulations of mesoderm and endoderm is not random but rather appears to be controlled, both temporally and spatially (Kinder et al. 1999). For instance, the first mesoderm cells to develop are derived from epiblast cells that move through the most posterior region of the streak. This mesoderm colonizes the developing yolk sac and gives rise to the hematopoietic and vascular cells of the blood islands. Epiblast cells that traverse the streak slightly later and in a more anterior position will form cardiac mesoderm, head mesenchyme, and paraxial mesoderm, whereas epiblast cells that move through the most anterior region of the primitive streak will generate endoderm and axial mesoderm, which gives rise to the notochord (Tam and Behringer 1997). Cells in the most anterior region of the epiblast that do not move through the primitive streak will form ectoderm. While the mechanisms controlling epiblast migration and mesoderm and endoderm induction are not fully understood in the mouse, expression analysis and gene targeting studies have shown that members of the TGF $\beta$ family including BMP4 (Hogan 1996) and nodal (Conlon et al. 1994; Schier and Shen 2000) as well as members of the Wnt (Yamaguchi 2001) and FGF (Yamaguchi and Rossant 1995; Sun et al. 1999) families play important roles in these processes.

\section{Modeling embryonic development with ES cells}

Cells with characteristics of primitive ectoderm have been identified in ES cell differentiation cultures. Rathjen et al. (1999) discovered that media conditioned by a hepatocellular carcinoma cell line could promote the synchronous differentiation of ES cells to a homoge- neous population of cells that grew as a monolayer and expressed fgf5 but not rex1. These cells, named early primitive ectoderm-like (EPL) cells, were unable to contribute to chimerism following injection into blastocysts. When differentiated in culture, EPL cells formed EBs and generated mesoderm and derivative cell populations more rapidly and efficiently than EBs from ES cells (Lake et al. 2000). These findings support the interpretation that EPL cells are similar to the primitive ectoderm of the embryo and, as such, represent the initial stage of differentiation from ES cells. While these studies demonstrate that this crude conditioned medium promotes the development of EPL cells from ES cells, the factors and signaling pathways regulating this differentiation step in culture remain to be determined.

Although it is unlikely that a structure comparable to the primitive streak develops in ES cell cultures, it will be important to mimic the induction events associated with different regions of the streak that lead to the development of specific cell populations. To date, the regulation of early germ layer induction in ES cell cultures remains poorly understood, as most studies have carried out the differentiation in the presence of FCS, which consists of undefined mixtures of growth factors and inhibitors. The limited number of studies that have investigated germ layer induction in ES cell differentiation cultures have provided evidence that the same sets of molecules regulating these decisions in the embryo are also active in vitro.

ES cells will generate neuroectoderm when differentiated as EBs or as a monolayer in the absence of serum and inducing molecules (Wiles and Johansson 1999; Ying et al. 2003b). Using ES cells with the GFP cDNA targeted to the neuroectoderm specific gene, Sox1, Ying et al. (2003b) were able to demonstrate that up to $60 \%$ of the cells in monolayer cultures formed neuroectoderm in serum-free cultures. Differentiation to neuroectoderm in these cultures did not appear to represent a "default" pathway but rather was dependent on FGF signaling (Ying et al. 2003b). Addition of BMP4 to serum-free cultures inhibited the development of neuroectoderm and led to the induction of mesoderm (Finley et al. 1999; Wiles and Johansson 1999; Ying et al. 2003b). Addition of serum resulted in a similar inhibition of neuroectoderm development. Further support for a neural inhibitory role for BMP has been provided by studies demonstrating that expression of the BMP antagonist noggin in ES cells promotes neural differentiation (Gratsch and O'Shea 2002). The inhibition of neural differentiation by BMP4 in the ES cell model is consistent with findings in Xenopus that show that noggin and chordin, inhibitors of BMP4, induce neural development (Sasai et al. 1995; Wilson et al. 1997).

Induction with both BMP4 and VEGF in serum-free ES cell differentiation cultures resulted in the development of hematopoietic cells, indicating that the equivalent of posterior streak mesoderm was generated (Nakayama et al. 2000; Park et al. 2004). Further characterization of these populations will be required to determine if other mesoderm types are generated under these conditions. In 
addition to BMP, Wnt signaling also appears to play a pivotal role in germ layer induction in the ES cell cultures (Aubert et al. 2002). Inhibition of Wnt through the expression of the Wnt inhibitor Sfrp2 led to enhanced neural development in EBs. Conversely, expression of Wnt1 inhibited neural development.

To be able to track mesoderm induction during ES cell differentiation, we targeted the GFP cDNA to the brachyury gene, which is expressed throughout the primitive streak as well as in all nascent mesoderm (Fehling et al. 2003). Using this reporter line, it was possible to demonstrate that batches of serum selected for optimal hematopoietic development also induced significant amounts of mesoderm, as up to $80 \%$ of the total EB population expressed GFP by day 4 of differentiation. A typical induction profile over a 3-d differentiation period is shown in Figure 5. With this ES cell line, it is easy to quantify the development of the brachyury-expressing population under different conditions. This model will also enable one to determine if a particular factor is functioning at the level of mesoderm induction (brachyury expression) or its specification to a particular cell type. In serum-free cultures, brachyury was not induced, whereas genes indicative of neuroectoderm development were expressed, an observation consistent with the findings from the studies outlined above (Kubo et al. 2004).

In addition to serum, activin also induced high levels of GFP (Fig. 5). However, the populations that developed following activin induction differed from those following serum induction. Whereas serum efficiently generated mesoderm that gave rise to hematopoietic and vascular cells, activin induced a range of cell types that differed depending on the concentration of factor used (Kubo et al. 2004). Low concentrations of activin gave rise to skeletal muscle indicating induction of paraxial mesoderm, whereas high concentrations led to the development of definitive endoderm and derivative cell types. Increasing concentrations of activin resulted in a down-regulation of neuroectoderm genes, suggesting that, as with BMP4 and Wnt, activin signaling inhibited

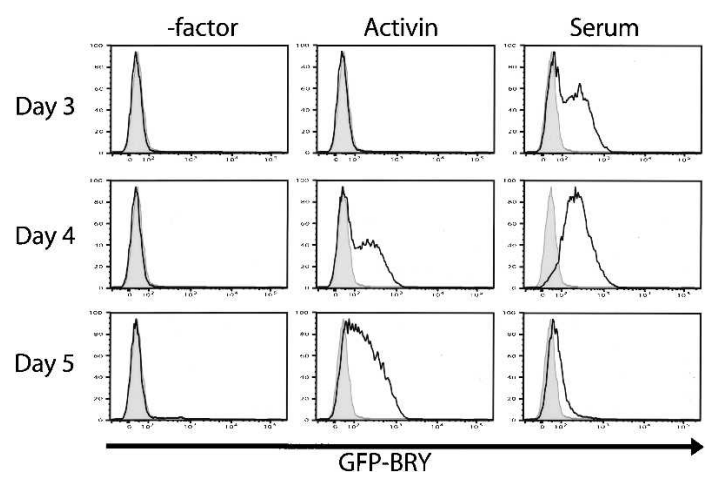

Figure 5. Induction of brachyury expression by serum and activin. Cells were differentiated in the absence of factors or in the presence of $100 \mathrm{ng} / \mathrm{mL}$ of activin or $10 \%$ FCS. The EBs were analyzed at days 3, 4, and 5 of differentiation. Shaded areas represent undifferentiated ES cells and open areas the EB-derived cells.

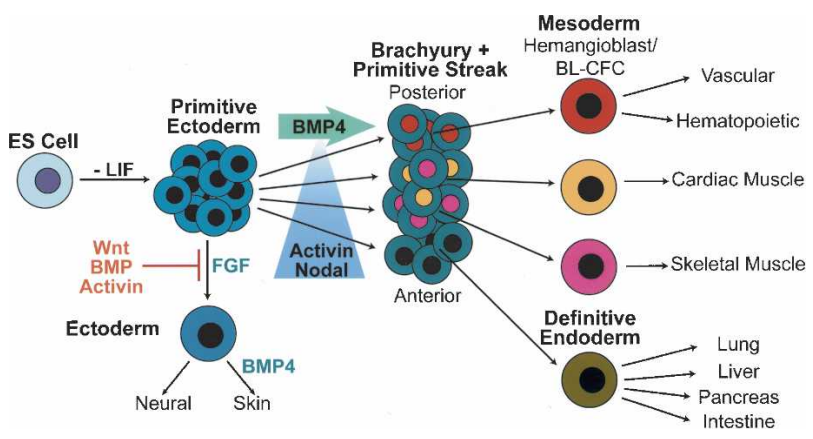

Figure 6. A scheme of ES cell differentiation depicting the development of primitive ectoderm and the primary germ layers and the role of specific factors in these processes. The brachyury-expressing cells are shown as a hypothetical primitive streak consisting of both posterior and anterior populations. The establishment of the derivative cell types from different brachyury populations is proposed, based on findings in the mouse embryo. BMP4 is shown to function to induce posterior mesoderm and skin. A gradient of activin/nodal signaling is indicated, with low concentrations inducing more posterior populations and high concentrations inducing endoderm, indicative of the anterior primitive streak. FGF is shown to play a role in neural induction, whereas Wnt, BMP, and activin are all implicated as inhibitors of the early stages of this pathway.

neural development in these cultures. Although activin did not induce hematopoietic cells directly, when the treated EBs were transferred to serum cultures for several days, this lineage did develop. Cell sorting studies revealed that both the mesoderm and endoderm populations developed from brachyury-positive cells. This is an important observation as it suggests that activin leads to the development of populations equivalent to those that are induced in different regions of the primitive streak (Fig. 6). High concentrations of activin induce the differentiation of cells similar to those generated in the anterior streak in the embryo, whereas lower concentrations induce cell types that are formed in the more posterior regions of the streak.

The demonstration that activin can induce both mesoderm and endoderm in ES cell cultures is consistent with findings in the Xenopus system, where it has been shown to induce these lineages from animal cap cells in culture (Green et al. 1992; Gamer and Wright 1995; Ninomiya et al. 1999). While these studies demonstrate that activin can induce mesoderm and endoderm in model systems, gene-targeting studies in mice indicate that it is not the endogenous factor that regulates these developmental decisions in the early embryo (Vassalli et al. 1994; Matzuk et al. 1995). One interpretation of these findings is that these activities of activin are likely mimicking the function of nodal, as both factors can bind the same receptors and thus initiate the same signaling events (Schier and Shen 2000). Unlike activin, nodal is essential for primitive streak formation as well as early mesoderm and endoderm development in vivo (Schier and Shen 2000; Whitman 2001).

The studies outlined in this section have only begun to probe the mechanisms that regulate the earliest stages of 
lineage development in ES cell differentiation cultures. The findings from them do, however, highlight the importance of understanding these early events, as the inducing molecules used in the differentiation cultures dramatically influence the cell populations that ultimately develop. These observations also serve a cautionary note that one set of conditions cannot be used to optimally generate progeny of all three germ layers. A model of ES cell differentiation, with the effects of the known inducers, is shown in Figure 6.

\section{Future directions}

The studies reviewed in the previous sections highlight the successes to date in differentiating cell populations from ES cells and in demonstrating the potential of using the model to investigate early development and generating cells for replacement therapy. As progress is made in establishing defined culture systems and selection strategies for the generation of highly enriched lineage-specific populations, the ES/EB model will be used in many different areas of biology and medicine. The following section and the summary in Figure 7 highlight three of these areas.

\section{Developmental biology}

The ability to access and manipulate populations representing early developmental stages in the ES cell differentiation cultures provides a new approach for addressing questions of lineage commitment. This system provides a model of early mammalian development that enables manipulations comparable to those carried out in other organisms such as Xenopus and zebrafish. As outlined in the previous sections, the ES cell system has already been used to study the role of specific genes in development; to isolate early-stage populations; to iden-

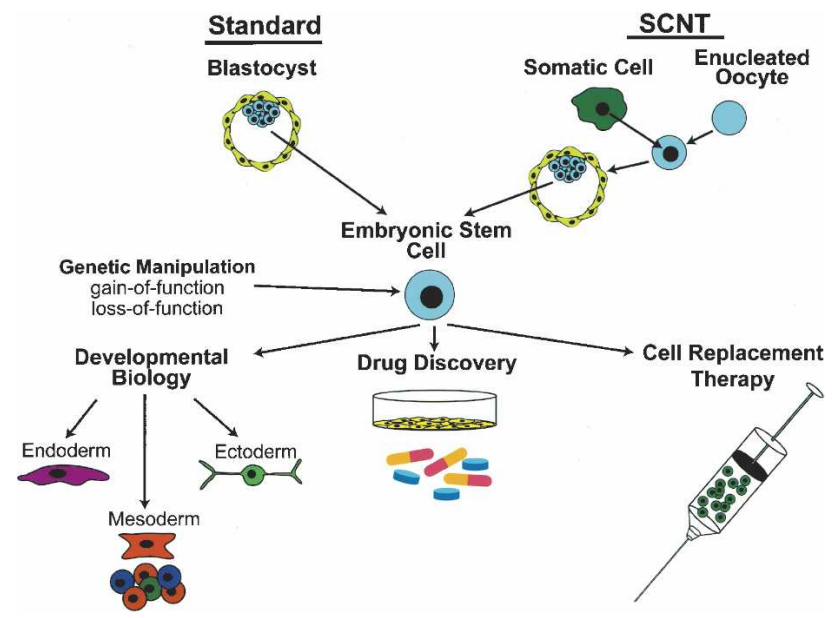

Figure 7. Potential uses of ES cells in basic research and medicine. (Standard) Generation of ES cells from normal blastocysts; (SCNT) generation of ES cells from blastocyst derived from SCNT (somatic cell nuclear transfer). tify progenitors that represent novel stages of hematopoietic, vascular, and neural development; and to begin to define the factors that regulate primary germ layer induction.

A critical area of future investigation is the regulation of germ layer induction and tissue specification using the ES cell differentiation cultures. These issues are most easily addressed using lineage-specific markers that allow quantification of the response to the specific factor or sets of factors being tested. When appropriate cell surface markers are not available, selectable markers can be targeted to lineage-specific genes as demonstrated for brachyury (Fehling et al. 2003), Pdx1 (Micallef et al. 2005), and Sox1 (Ying et al. 2003b). Given their role in the development of the early embryo, factors from the TGF $\beta$, Wnt, and FGF families would be obvious candidates to be tested. The outcome of these experiments will establish a role for the different factors in these early developmental steps and ultimately lead to the establishment of defined conditions that will enable efficient and reproducible lineage-specific induction in both mouse and human ES cell differentiation cultures.

The ES cell model is well suited for the identification, isolation, and characterization of cell populations representing the early stages of lineage commitment. The identification of EPL cells (Rathjen et al. 1999) and the isolation of mesoderm and neuroectoederm, through targeting of GFP to brachyury (Fehling et al. 2003) and Sox1 (Ying et al. 2003b), respectively, highlight the advantages of this model in isolating cell populations that are difficult to access in the early embryo. It will be important to expand this approach to introduce different selectable markers into genes that define distinct developmental steps within a given lineage. These strategies will not only provide progenitors for cell-based therapy, they will also generate closely related populations that can be used for the identification of genes involved in the development and maturation of the lineage under investigation.

Once genes have been identified, the ES cell system is an ideal model with which to study their role in lineage development. Gain-of-function studies can now be carried out with inducible systems that allow the expression of the gene of interest at specific stages in specific cell populations (Kyba et al. 2002). The ability to regulate expression through inducible vectors is an important consideration as certain genes display different functions in different cell types. Loss of function can be routinely achieved though homologous recombination (Joyner 1991). For in vitro analysis, both alleles of the gene under study need to be disrupted to create a homozygous null ES cell line. Although this approach can and has been used to study the role of different genes in early lineage commitment, disruption of function though homologous recombination is slow and labor-intensive and thus not appropriate for the analysis of large numbers of genes. An alternative promising strategy for downregulating gene expression is through the use of RNAi (Dykxhoorn et al. 2003) that can be delivered to both mouse and human ES cells with lentiviruses (Hamaguchi et al. 2000; Ma et al. 2003). Several studies have dem- 
onstrated that RNAi can be used to modify gene expression in undifferentiated ES cells as well as in EBs (Velkey and O'Shea 2003; Matin et al. 2004; Zippo et al. 2004). If future work shows that this approach is effective for a broad range of genes at different developmental stages, the use of RNAi will become a routine technology for gene function analysis in ES cell differentiation cultures.

All of these strategies can be applied to the human ES cell system. Of particular importance will be the investigation of the early developmental steps and the analysis of gene function, as these issues obviously cannot be addressed in the human embryo. With respect to loss-offunction approaches, there is only one report to date of targeting through homologous recombination (Zwaka and Thomson 2003). Whether or not gene targeting in hES cells will become a "routine" technology as it is with mouse cells remains to be determined. An important avenue of investigation with enormous potential is the generation and analysis of hES cell lines with genotypes characteristic of different diseases. Such lines have already been established from embryos carrying genetic diseases, identified through preimplantation diagnosis (Verlinsky et al. 2005). hES cell lines from patients suffering from a variety of different diseases can be generated through the use of somatic cell nuclear transfer (SCNT) (Hochedlinger and Jaenisch 2003). Such ES cell lines could be used to study the effects of specific disease mutations on lineage development, to establish new strategies to investigate the underlying causes of certain diseases, and as a model for testing new approaches for treating the diseases.

\section{Cell replacement therapy}

The application of ES cells that has received the most attention in recent years is as a novel source of cells for cell replacement therapy for the treatment of a wide range of debilitating diseases. Type I diabetes, cardiovascular disease, Parkinson's disease, blood cell diseases, and certain types of liver disease are considered candidates for cell replacement therapy. As indicated in this review, transplantation of specific ES-cell-derived cells into pre-clinical models of human disease is already underway. The success to date in delivering appropriate cell populations and demonstrating their functional capacity in vivo is limited. For this application to advance to the next step, several outstanding issues need to be addressed.

The first relates to the type and number of cells to be transplanted. One of the most important questions is at what stage of maturation should cells be transplanted. The answer to this will depend to a large extent on the lineage under investigation. For example, when considering hepatocyte replacement therapy, one might isolate and transplant relatively mature cells that are known to retain substantial proliferative and regenerative potential (Overturf et al. 1997). Similarly, when replacing pancreatic $\beta$-cell function, it may be essential to develop methods to induce end-stage maturation of the cells prior to transplantation. In contrast, sustained replace- ment of the hematopoietic system will require transplantation of the most immature cells of the system, the HSC. For cardiomyocyte replacement, different developmental stages will need to be tested. The number of cells to be transplanted will also depend on the lineage and stage of development. To address these issues, it will be important to first define the mechanisms controlling development of the desired lineage. With this information, optimal conditions for the generation of the appropriate cell populations can be developed.

A second concern when considering cell replacement therapy with ES-cell-derived populations is the danger associated with contamination of the graft with residual undifferentiated ES cells. Transplantation of ES cells can result in the development of teratomas (Evans and Kaufman 1983; Thomson et al. 1998). Techniques that allow for the selection of the lineage to be transplanted represent the first step in reducing the number of ES cells in the graft (Klug et al. 1996; Li et al. 1998). A second approach is the use of strategies to eliminate undifferentiated ES cells from the graft (Billon et al. 2002). With a combination of positive and negative selection, it should be possible to reproducibly generate grafts free of undifferentiated ES cells.

A third obstacle to be overcome is donor/recipient compatibility and graft rejection. One solution to this problem would be to bank large numbers of ES cell lines that would include a significant portion of the histocompatibility types in the population. A second strategy is to generate individualized ES cell lines through SCNT (Hochedlinger and Jaenisch 2003). With this approach, the cells used for transplantation would be genetically identical to those of the patient. Both mouse and human ES cells have been generated using SCNT (Munsie et al. 2000; Wakayama et al. 2001; Rideout et al. 2002; Hwang et al. 2004). An ethical and practical limitation of SCNT is the requirement of oocytes. The development of oocytes from differentiated ES cells may provide one solution to this problem (Hubner et al. 2003).

\section{Drug discovery}

In addition to developmental biology and cell-based therapy, the ES cell model has widespread applications in the areas of drug discovery and drug development. With respect to drug development, cell types such as cardiomyocytes and hepatocytes generated from hES cells could provide ideal populations for predictive toxicology. These human cells could reveal the toxicity of certain drugs that might not be detected using conventional assays that rely on animal models. Other advantages of such ES-cell-based assays include (1) the requirement of significantly less test compound than in vivo assays, enabling earlier use in the drug discovery phase, resulting in earlier prioritization between drug leads; and (2) the availability of cell lines with different genotypes that could be used to identify clinically important pharmacogenomic specific drug responses and/or toxicities.

ES cells offer many different strategies to develop drugs that can be used for regenerative medicine, that is, 
the therapeutic regrowth and/or repair of damaged cells. A unique strength of the ES cell system is the ability to engineer the ES cells to enable one to easily quantify the effect of drugs. This strategy has been discussed previously in this review, and could be used for drug discovery applications by introducing reporter molecules, such as GFP, into genes indicative of the development of specific progenitor populations or into genes associated with cell maturation and function. These customized assays could be used to identify those compounds that induce the growth and/or maturation of the cell types of interest. This capability offers a unique opportunity to develop clinically relevant commercial-grade pharmaceutical screening assays for certain human cell types that are not possible to produce by any other approach. An example of this approach would be the development of an ES cell line engineered to express an appropriate reporter in genes associated with pancreatic development or $\beta$-cell maturation. Screens with such ES cell lines could lead to the identification of molecules that promote the growth of specific pancreatic progenitors or those that enhance the maturation of the insulin-producing $\beta$-cells.

In addition to genetically modified cells, hES cell lines with genotypes characteristic of various genetic diseases could not only provide novel insights into the mechanisms of the disease process, but also offer powerful screening systems for developing drugs for treating those diseases. Given the successes in lineage-specific differentiation of ES cells in recent years, these approaches are already under preliminary evaluation. As the conditions for the differentiation of hES cells are optimized, ES-cellbased screens could be incorporated into drug discovery platforms of many biotechnology and pharmaceutical companies.

\section{Acknowledgments}

I thank Jim Palis, Ralph Snodgrass, Hans Snoeck, and members of my lab for many helpful discussions and critical reading of the manuscript and Dr. Steve Kattman for assistance with generating the figures.

\section{References}

Ali, N.N., Edgar, A.J., Samadikuchaksaraei, A., Timson, C.M., Romanska, H.M., Polak, J.M., and Bishop, A.E. 2002. Derivation of type II alveolar epithelial cells from murine embryonic stem cells. Tissue Eng. 8: 541-550.

Amit, M., Carpenter, M.K., Inokuma, M.S., Chiu, C.P., Harris, C.P., Waknitz, M.A., Itskovitz-Eldor, J., and Thomson, J.A. 2000. Clonally derived human embryonic stem cell lines maintain pluripotency and proliferative potential for prolonged periods of culture. Dev. Biol. 227: 271-278.

Arceci, R.J., King, A.A., Simon, M.C., Orkin, S.H., and Wilson, D.B. 1993. Mouse GATA-4: A retinoic acid-inducible GATA-binding transcription factor expressed in endodermally derived tissues and heart. Mol. Cell. Biol. 13: 22352246.

Asahina, K., Fujimori, H., Shimizu-Saito, K., Kumashiro, Y., Okamura, K., Tanaka, Y., Teramoto, K., Arii, S., and Teraoka, H. 2004. Expression of the liver-specific gene Cyp7a1 reveals hepatic differentiation in embryoid bodies derived from mouse embryonic stem cells. Genes Cells 9: 1297-1308.

Assady, S., Maor, G., Amit, M., Itskovitz-Eldor, J., Skorecki, K.L., and Tzukerman, M. 2001. Insulin production by human embryonic stem cells. Diabetes 50: 1691-1697.

Aubert, J., Dunstan, H., Chambers, I., and Smith, A. 2002. Functional gene screening in embryonic stem cells implicates Wnt antagonism in neural differentiation. Nat. Biotechnol. 20: $1240-1245$.

Bagutti, C., Wobus, A.M., Fassler, R., and Watt, F.M. 1996. Differentiation of embryonal stem cells into keratinocytes: Comparison of wild-type and $\beta 1$ integrin-deficient cells. Dev. Biol. 179: 184-196.

Bain, G., Kitchens, D., Yao, M., Huettner, J.E., and Gottlieb, D.I. 1995. Embryonic stem cells express neuronal properties in vitro. Dev. Biol. 168: 342-357.

Banach, K., Halbach, M.D., Hu, P., Hescheler, J., and Egert, U. 2003. Development of electrical activity in cardiac myocyte aggregates derived from mouse embryonic stem cells. Am. J. Physiol. Heart Circ. Physiol. 284: H2114-H2123.

Barberi, T., Klivenyi, P., Calingasan, N.Y., Lee, H., Kawamata, H., Loonam, K., Perrier, A.L., Bruses, J., Rubio, M.E., Topf, N., et al. 2003. Neural subtype specification of fertilization and nuclear transfer embryonic stem cells and application in Parkinsonian mice. Nat. Biotechnol. 21: 1200-1207.

Barker, J. 1968. Development of the mouse hematopoietic system I. Types of hemoglobin produced in embryonic yolk sac and liver. Dev. Biol. 18: 14-29.

Bautch, V.L., Stanford, W.L., Rapoport, R., Russell, S., Byrum, R.S., and Futch, T.A. 1996. Blood island formation in attached cultures of murine embryonic stem cells. Dev. Dyn. 205: 1-12.

Bautch, V.L., Redick, S.D., Scalia, A., Harmaty, M., Carmeliet, P., and Rapoport, R. 2000. Characterization of the vasculogenic block in the absence of vascular endothelial growth factor-A. Blood 95: 1979-1987.

Beddington, R.S. 1983. The origin of foetal tissues during gastrulation in the rodent. Dev. Mamm. 5: 1-32.

Beddington, R.S. and Robertson, E.J. 1989. An assessment of the developmental potential of embryonic stem cells in the midgestation mouse embryo. Development 105: 733-737.

Begley, C.G., Aplan, P.D., Denning, S.M., Haynes, B.F., Waldmann, T.A., and Kirsch, I.R. 1989. The gene SCL is expressed during early hematopoiesis and encodes a differentiation-related DNA-binding motif. Proc. Nat1. Acad. Sci. 86: $10128-10132$.

Ben-Hur, T., Idelson, M., Khaner, H., Pera, M., Reinhartz, E., Itzik, A., and Reubinoff, B.E. 2004. Transplantation of human embryonic stem cell-derived neural progenitors improves behavioral deficit in Parkinsonian rats. Stem Cells 22: 1246-1255.

Billon, N., Jolicoeur, C., Ying, Q.L., Smith, A., and Raff, M. 2002. Normal timing of oligodendrocyte development from genetically engineered, lineage-selectable mouse ES cells. J. Cell Sci. 115: 3657-3665.

Blyszczuk, P., Czyz, J., Kania, G., Wagner, M., Roll, U., St-Onge, L., and Wobus, A.M. 2003. Expression of Pax4 in embryonic stem cells promotes differentiation of nestin-positive progenitor and insulin-producing cells. Proc. Nat1. Acad. Sci. 100: $998-1003$.

Boheler, K.R., Czyz, J., Tweedie, D., Yang, H.T., Anisimov, S.V., and Wobus, A.M. 2002. Differentiation of pluripotent embryonic stem cells into cardiomyocytes. Circ. Res. 91: 189201.

Bradley, A., Evans, M., Kaufman, M.H., and Robertson, E. 1984. Formation of germ-line chimaeras from embryo-derived 
teratocarcinoma cell lines. Nature 309: 255-256.

Brotherton, T., Chui, D., Gauldie, J., and Patterson, M. 1979. Hemoglobin ontogeny during normal mouse fetal development. Proc. Natl. Acad. Sci. 76: 2853-2857.

Brustle, O., Spiro, A.C., Karram, K., Choudhary, K., Okabe, S., and McKay, R.D. 1997. In vitro-generated neural precursors participate in mammalian brain development. Proc. Natl. Acad. Sci. 94: 14809-14814.

Brustle, O., Jones, K.N., Learish, R.D., Karram, K., Choudhary, K., Wiestler, O.D., Duncan, I.D., and McKay, R.D. 1999. Embryonic stem cell-derived glial precursors: A source of myelinating transplants. Science 285: 754-756.

Burkert, U., von Ruden, T., and Wagner, E.F. 1991. Early fetal hematopoietic development from in vitro differentiated embryonic stem cells. New Biol. 3: 698-708.

Burt, R.K., Verda, L., Kim, D.A., Oyama, Y., Luo, K., and Link, C. 2004. Embryonic stem cells as an alternate marrow donor source: Engraftment without graft-versus-host disease. J. Exp. Med. 199: 895-904.

Buttery, L.D., Bourne, S., Xynos, J.D., Wood, H., Hughes, F.J., Hughes, S.P., Episkopou, V., and Polak, J.M. 2001. Differentiation of osteoblasts and in vitro bone formation from murine embryonic stem cells. Tissue Eng. 7: 89-99.

Carmeliet, P., Ferreira, V., Breier, G., Pollefeyt, S., Kieckens, L., Gertsenstein, M., Fahrig, M., Vandenhoeck, A., Harpal, K., Eberhardt, C., et al. 1996. Abnormal blood vessel development and lethality in embryos lacking a single VEGF allele. Nature 380: 435-439.

Carotta, S., Pilat, S., Mairhofer, A., Schmidt, U., Dolznig, H., Steinlein, P., and Beug, H. 2004. Directed differentiation and mass cultivation of pure erythroid progenitors from mouse embryonic stem cells. Blood 104: 1873-1880.

Cerdan, C., Rouleau, A., and Bhatia, M. 2004. VEGF-A165 augments erythropoietic development from human embryonic stem cells. Blood 103: 2504-2512.

Chadwick, K., Wang, L., Li, L., Menendez, P., Murdoch, B., Rouleau, A., and Bhatia, M. 2003. Cytokines and BMP-4 promote hematopoietic differentiation of human embryonic stem cells. Blood 102: 906-915.

Chambers, I. and Smith, A. 2004. Self-renewal of teratocarcinoma and embryonic stem cells. Oncogene 23: 7150-7160.

Chambers, I., Colby, D., Robertson, M., Nichols, J., Lee, S., Tweedie, S., and Smith, A. 2003. Functional expression cloning of Nanog, a pluripotency sustaining factor in embryonic stem cells. Cell 113: 643-655.

Chinzei, R., Tanaka, Y., Shimizu-Saito, K., Hara, Y., Kakinuma, S., Watanabe, M., Teramoto, K., Arii, S., Takase, K., Sato, C., et al. 2002. Embryoid-body cells derived from a mouse embryonic stem cell line show differentiation into functional hepatocytes. Hepatology 36: 22-29.

Cho, S.K., Webber, T.D., Carlyle, J.R., Nakano, T., Lewis, S.M., and Zuniga-Pflucker, J.C. 1999. Functional characterization of B lymphocytes generated in vitro from embryonic stem cells. Proc. Nat1. Acad. Sci. 96: 9797-9802.

Choi, K., Kennedy, M., Kazarov, A., Papadimitriou, J.C., and Keller, G. 1998. A common precursor for hematopoietic and endothelial cells. Development 125: 725-732.

Clark, A.T., Bodnar, M.S., Fox, M., Rodriquez, R.T., Abeyta, M.J., Firpo, M.T., and Pera, R.A. 2004. Spontaneous differentiation of germ cells from human embryonic stem cells in vitro. Hum. Mol. Genet. 13: 727-739.

Colman, A. 2004. Making new $\beta$ cells from stem cells. Semin. Cell Dev. Biol. 15: 337-345.

Conlon, F.L., Lyons, K.M., Takaesu, N., Barth, K.S., Kispert, A., Herrmann, B., and Robertson, E.J. 1994. A primary requirement for nodal in the formation and maintenance of the primitive streak in the mouse. Development 120: 19191928.

Coraux, C., Hilmi, C., Rouleau, M., Spadafora, A., Hinnrasky, J., Ortonne, J.P., Dani, C., and Aberdam, D. 2003. Reconstituted skin from murine embryonic stem cells. Curr. Biol. 13: 849-853.

Coucouvanis, E. and Martin, G.R. 1995. Signals for death and survival: A two-step mechanism for cavitation in the vertebrate embryo. Cell 83: 279-287.

Cumano, A., Ferraz, J.C., Klaine, M., Di Santo, J.P., and Godin, I. 2001. Intraembryonic, but not yolk sac hematopoietic precursors, isolated before circulation, provide long-term multilineage reconstitution. Immunity 15: 477-485.

Daheron, L., Opitz, S.L., Zaehres, H., Lensch, W.M., Andrews, P.W., Itskovitz-Eldor, J., and Daley, G.Q. 2004. LIF/STAT3 signaling fails to maintain self-renewal of human embryonic stem cells. Stem Cells 22: 770-778.

Dani, C., Smith, A.G., Dessolin, S., Leroy, P., Staccini, L., Villageois, P., Darimont, C., and Ailhaud, G. 1997. Differentiation of embryonic stem cells into adipocytes in vitro. J. Cell Sci. 110: 1279-1285.

Dell'Era, P., Ronca, R., Coco, L., Nicoli, S., Metra, M., and Presta, M. 2003. Fibroblast growth factor receptor-1 is essential for in vitro cardiomyocyte development. Circ. Res. 93: 414-420.

Deltour, L., Leduque, P., Blume, N., Madsen, O., Dubois, P., Jami, J., and Bucchini, D. 1993. Differential expression of the two nonallelic proinsulin genes in the developing mouse embryo. Proc. Natl. Acad. Sci. 90: 527-531.

Devaskar, S.U., Singh, B.S., Carnaghi, L.R., Rajakumar, P.A., and Giddings, S.J. 1993. Insulin II gene expression in rat central nervous system. Regul. Pept. 48: 55-63.

Dickson, M.C., Martin, J.S., Cousins, F.M., Kulkarni, A.B., Karlsson, S., and Akhurst, R.J. 1995. Defective haematopoiesis and vasculogenesis in transforming growth factor- $\beta 1$ knock out mice. Development 121: 1845-1854.

Dieterlen-Lievre, F. 1975. On the origin of haemopoietic stem cells in the avian embryo: An experimental approach. J. Embryol. Exp. Morphol. 33: 607-619.

Ding, J., Yang, L., Yan, Y.T., Chen, A., Desai, N., WynshawBoris, A., and Shen, M.M. 1998. Cripto is required for correct orientation of the anterior-posterior axis in the mouse embryo. Nature 395: 702-707.

Doetschman, T.C., Eistetter, H., Katz, M., Schmidt, W., and Kemler, R. 1985. The in vitro development of blastocystderived embryonic stem cell lines: Formation of visceral yolk sac, blood islands and myocardium. J. Embryol. Exp. Morphol. 87: 27-45.

D'Souza, S., Elefanty, A.G., and Keller, G. 2005. Scl/Tal-1 is essential for hematopoietic commitment of the hemangioblast, but not for its development. Blood (in press).

Dykxhoorn, D.M., Novina, C.D., and Sharp, P.A. 2003. Killing the messenger: Short RNAs that silence gene expression. Nat. Rev. Mol. Cell Biol. 4: 457-467.

Dziadek, M. and Adamson, E. 1978. Localization and synthesis of $\alpha$ foetoprotein in post-implantation mouse embryos. J. Embryol. Exp. Morphol. 43: 289-313.

Ema, M., Faloon, P., Zhang, W.J., Hirashima, M., Reid, T., Stanford, W.L., Orkin, S., Choi, K., and Rossant, J. 2003. Combinatorial effects of Flk1 and Tall on vascular and hematopoietic development in the mouse. Genes \& Dev. 17: 380-393.

Eto, K., Murphy, R., Kerrigan, S.W., Bertoni, A., Stuhlmann, H., Nakano, T., Leavitt, A.D., and Shattil, S.J. 2002. Megakaryocytes derived from embryonic stem cells implicate CalDAGGEFI in integrin signaling. Proc. Natl. Acad. Sci. 99: 1281912824. 
Evans, M. and Kaufman, M. 1981. Establishment in culture of pluripotent cells from mouse embryos. Nature 292: 154156.

- 1983. Pluripotential cells grown directly from normal mouse embryos. Cancer Surv. 2: 185-208.

Fairchild, P.J., Nolan, K.F., Cartland, S., Graca, L., and Waldmann, H. 2003. Stable lines of genetically modified dendritic cells from mouse embryonic stem cells. Transplantation 76: 606-608.

Faloon, P., Arentson, E., Kazarov, A., Deng, C.X., Porcher, C., Orkin, S., and Choi, K. 2000. Basic fibroblast growth factor positively regulates hematopoietic development. Development 127: 1931-1941.

Fehling, H.J., Lacaud, G., Kubo, A., Kennedy, M., Robertson, S., Keller, G., and Kouskoff, V. 2003. Tracking mesoderm induction and its specification to the hemangioblast during embryonic stem cell differentiation. Development 130: 4217-4227.

Ferkowicz, M.J., Starr, M., Xie, X., Li, W., Johnson, S.A., Shelley, W.C., Morrison, P.R., and Yoder, M.C. 2003. CD41 expression defines the onset of primitive and definitive hematopoiesis in the murine embryo. Development 130: 43934403.

Ferrara, N., Carver-Moore, K., Chen, H., Dowd, M., Lu, L., O'Shea, K.S., Powell-Braxton, L., Hillan, K.J., and Moore, M.W. 1996. Heterozygous embryonic lethality induced by targeted inactivation of the VEGF gene. Nature 380: 439442.

Finley, M.F., Devata, S., and Huettner, J.E. 1999. BMP-4 inhibits neural differentiation of murine embryonic stem cells. J. Neurobiol. 40: 271-287.

Fong, G.H., Rossant, J., Gertsenstein, M., and Breitman, M.L. 1995. Role of the Flt-1 receptor tyrosine kinase in regulating the assembly of vascular endothelium. Nature 376: 66-70.

Fong, G.H., Klingensmith, J., Wood, C.R., Rossant, J., and Breitman, M.L. 1996. Regulation of flt-1 expression during mouse embryogenesis suggests a role in the establishment of vascular endothelium. Dev. Dyn. 207: 1-10.

Fujikura, J., Yamato, E., Yonemura, S., Hosoda, K., Masui, S., Nakao, K., Miyazaki Ji, J., and Niwa, H. 2002. Differentiation of embryonic stem cells is induced by GATA factors. Genes \& Dev. 16: 784-789.

Gamer, L.W. and Wright, C.V. 1995. Autonomous endodermal determination in Xenopus: Regulation of expression of the pancreatic gene XlHbox 8. Dev. Biol. 171: 240-251.

Gardner, R.L. and Rossant, J. 1979. Investigation of the fate of 4-5 day post-coitum mouse inner cell mass cells by blastocyst injection. J. Embryol. Exp. Morphol. 52: 141-152.

Geijsen, N., Horoschak, M., Kim, K., Gribnau, J., Eggan, K., and Daley, G.Q. 2004. Derivation of embryonic germ cells and male gametes from embryonic stem cells. Nature 427: 148154.

Giddings, S.J., King, C.D., Harman, K.W., Flood, J.F., and Carnaghi, L.R. 1994. Allele specific inactivation of insulin 1 and 2 , in the mouse yolk sac, indicates imprinting. Nat. Genet. 6: $310-313$.

Ginis, I., Luo, Y., Miura, T., Thies, S., Brandenberger, R., Gerecht-Nir, S., Amit, M., Hoke, A., Carpenter, M.K., Itskovitz-Eldor, J., et al. 2004. Differences between human and mouse embryonic stem cells. Dev. Biol. 269: 360380 .

Ginsburg, M., Snow, M.H., and McLaren, A. 1990. Primordial germ cells in the mouse embryo during gastrulation. Development 110: 521-528.

Godin, I., Dieterlen-Lièvre, F., and Cumano, A. 1995. Emergence of multipotent hemopoietic cells in the yolk sac and paraaortic splanchnopleura in mouse embryos, beginning at 8.5 days postcoitus. Proc. Natl. Acad. Sci. 92: 773-777.

Gratsch, T.E. and O'Shea, K.S. 2002. Noggin and chordin have distinct activities in promoting lineage commitment of mouse embryonic stem (ES) cells. Dev. Biol. 245: 83-94.

Green, J.B., New, H.V., and Smith, J.C. 1992. Responses of embryonic Xenopus cells to activin and FGF are separated by multiple dose thresholds and correspond to distinct axes of the mesoderm. Cell 71: 731-739.

Haar, J.L. and Ackerman, G.A. 1971. A phase and electron microscopic study of vasculogenesis and erythropoiesis in the yolk sac of the mouse. Anat. Rec. 170: 199-224.

Hamaguchi, I., Woods, N.B., Panagopoulos, I., Andersson, E., Mikkola, H., Fahlman, C., Zufferey, R., Carlsson, L., Trono, D., and Karlsson, S. 2000. Lentivirus vector gene expression during ES cell-derived hematopoietic development in vitro. J. Virol. 74: 10778-10784.

Hamaguchi-Tsuru, E., Nobumoto, A., Hirose, N., Kataoka, S., Fujikawa-Adachi, K., Furuya, M., and Tominaga, A. 2004. Development and functional analysis of eosinophils from murine embryonic stem cells. Br. J. Haematol. 124: 819827.

Hamazaki, T., Iiboshi, Y., Oka, M., Papst, P.J., Meacham, A.M., Zon, L.I., and Terada, N. 2001. Hepatic maturation in differentiating embryonic stem cells in vitro. FEBS Lett. 497: 15-19.

Hamazaki, T., Oka, M., Yamanaka, S., and Terada, N. 2004. Aggregation of embryonic stem cells induces Nanog repression and primitive endoderm differentiation. I. Cell Sci. 117: 5681-5686.

Haub, O. and Goldfarb, M. 1991. Expression of the fibroblast growth factor-5 gene in the mouse embryo. Development 112: 397-406.

He, J.Q., Ma, Y., Lee, Y., Thomson, J.A., and Kamp, T.J. 2003. Human embryonic stem cells develop into multiple types of cardiac myocytes: Action potential characterization. Circ. Res. 93: 32-39.

Hebert, J.M., Boyle, M., and Martin, G.R. 1991. mRNA localization studies suggest that murine FGF-5 plays a role in gastrulation. Development 112: 407-415.

Hescheler, J., Fleischmann, B.K., Lentini, S., Maltsev, V.A., Rohwedel, J., Wobus, A.M., and Addicks, K. 1997. Embryonic stem cells: A model to study structural and functional properties in cardiomyogenesis. Cardiovasc. Res. 36: 149162.

Hidaka, K., Lee, J.K., Kim, H.S., Ihm, C.H., Iio, A., Ogawa, M., Nishikawa, S., Kodama, I., and Morisaki, T. 2003. Chamberspecific differentiation of Nkx2.5-positive cardiac precursor cells from murine embryonic stem cells. FASEB J. 17: 740742.

Hirashima, M., Kataoka, H., Nishikawa, S., and Matsuyoshi, N. 1999. Maturation of embryonic stem cells into endothelial cells in an in vitro model of vasculogenesis. Blood 93: 12531263.

Hochedlinger, K. and Jaenisch, R. 2003. Nuclear transplantation, embryonic stem cells, and the potential for cell therapy. N. Engl. J. Med. 349: 275-286.

Hogan, B.L. 1996. Bone morphogenetic proteins: Multifunctional regulators of vertebrate development. Genes \& Dev. 10: $1580-1594$.

Hori, Y., Rulifson, I.C., Tsai, B.C., Heit, J.J., Cahoy, J.D., and Kim, S.K. 2002. Growth inhibitors promote differentiation of insulin-producing tissue from embryonic stem cells. Proc. Nat1. Acad. Sci. 99: 16105-16110.

Hornstein, E. and Benvenisty, N. 2004. The "brainy side" of human embryonic stem cells. J. Neurosci. Res. 76: 169-173.

Huber, T.L., Kouskoff, V., Fehling, H.J., Palis, J., and Keller, G. 
2004. Haemangioblast commitment is initiated in the primitive streak of the mouse embryo. Nature 432: 625-630.

Hubner, K., Fuhrmann, G., Christenson, L.K., Kehler, J., Reinbold, R., De La Fuente, R., Wood, J., Strauss III, J.F., Boiani, M., and Scholer, H.R. 2003. Derivation of oocytes from mouse embryonic stem cells. Science 300: 1251-1256.

Hwang, W.S., Ryu, Y.J., Park, J.H., Park, E.S., Lee, E.G., Koo, J.M., Jeon, H.Y., Lee, B.C., Kang, S.K., Kim, S.J., et al. 2004. Evidence of a pluripotent human embryonic stem cell line derived from a cloned blastocyst. Science 303: 1669-1674.

Jones, E.A., Tosh, D., Wilson, D.I., Lindsay, S., and Forrester, L.M. 2002. Hepatic differentiation of murine embryonic stem cells. Exp. Cell Res. 272: 15-22.

Jordan, C., McKearn, J., and Lemischka, I. 1990. Cellular and developmental properties of fetal hematopoietic stem cells. Cell 61: 953-963.

Joyner, A.L. 1991. Gene targeting and gene trap screens using embryonic stem cells: New approaches to mammalian development. Bioessays 13: 649-656.

Kabrun, N., Buhring, H.J., Choi, K., Ullrich, A., Risau, W., and Keller, G. 1997. Flk-1 expression defines a population of early embryonic hematopoietic precursors. Development 124: 2039-2048.

Kahan, B.W., Jacobson, L.M., Hullett, D.A., Ochoada, J.M., Oberley, T.D., Lang, K.M., and Odorico, J.S. 2003. Pancreatic precursors and differentiated islet cell types from murine embryonic stem cells: An in vitro model to study islet differentiation. Diabetes 52: 2016-2024.

Kanai-Azuma, M., Kanai, Y., Gad, J.M., Tajima, Y., Taya, C., Kurohmaru, M., Sanai, Y., Yonekawa, H., Yazaki, K., Tam, P.P., et al. 2002. Depletion of definitive gut endoderm in Sox17-null mutant mice. Development 129: 2367-2379.

Kanno, S., Kim, P.K., Sallam, K., Lei, J., Billiar, T.R., and Shears II, L.L. 2004. Nitric oxide facilitates cardiomyogenesis in mouse embryonic stem cells. Proc. Natl. Acad. Sci. 101: 12277-12281.

Kaufman, D.S., Hanson, E.T., Lewis, R.L., Auerbach, R., and Thomson, J.A. 2001. Hematopoietic colony-forming cells derived from human embryonic stem cells. Proc. Natl. Acad. Sci. 98: 10716-10721.

Kawai, T., Takahashi, T., Esaki, M., Ushikoshi, H., Nagano, S., Fujiwara, H., and Kosai, K. 2004. Efficient cardiomyogenic differentiation of embryonic stem cell by fibroblast growth factor 2 and bone morphogenetic protein 2. Circ. J. 68: 691702.

Kawasaki, H., Mizuseki, K., Nishikawa, S., Kaneko, S., Kuwana, Y., Nakanishi, S., Nishikawa, S.I., and Sasai, Y. 2000. Induction of midbrain dopaminergic neurons from ES cells by stromal cell-derived inducing activity. Neuron 28: 31-40.

Kearney, J.B., Ambler, C.A., Monaco, K.A., Johnson, N., Rapoport, R.G., and Bautch, V.L. 2002. Vascular endothelial growth factor receptor Flt-1 negatively regulates developmental blood vessel formation by modulating endothelial cell division. Blood 99: 2397-2407.

Kehat, I. and Gepstein, L. 2003. Human embryonic stem cells for myocardial regeneration. Heart Fail. Rev. 8: 229-236.

Kehat, I., Kenyagin-Karsenti, D., Snir, M., Segev, H., Amit, M., Gepstein, A., Livne, E., Binah, O., Itskovitz-Eldor, J., and Gepstein, L. 2001. Human embryonic stem cells can differentiate into myocytes with structural and functional properties of cardiomyocytes. J. Clin. Invest. 108: 407-414.

Kehat, I., Khimovich, L., Caspi, O., Gepstein, A., Shofti, R., Arbel, G., Huber, I., Satin, J., Itskovitz-Eldor, J., and Gepstein, L. 2004. Electromechanical integration of cardiomyocytes derived from human embryonic stem cells. Nat. Biotechnol. 22: 1282-1289.
Keller, G. 1995. In vitro differentiation of embryonic stem cells. Curr. Opin. Cell Biol. 7: 862-869.

Keller, G., Kennedy, M., Papayannopoulou, T., and Wiles, M. 1993. Hematopoietic commitment during embryonic stem cell differentiation in culture. Mol. Cell. Biol. 13: 473-486.

Keller, G., Lacaud, G., and Robertson, S. 1999. Development of the hematopoietic system in the mouse. Exp. Hematol. 27: 777-787.

Kennedy, M., Firpo, M., Choi, K., Wall, C., Robertson, S., Kabrun, N., and Keller, G. 1997. A common precursor for primitive and definitive hematopoiesis. Nature 386: 488 493.

Kim, J.H., Auerbach, J.M., Rodriguez-Gomez, J.A., Velasco, I., Gavin, D., Lumelsky, N., Lee, S.H., Nguyen, J., SanchezPernaute, R., Bankiewicz, K., et al. 2002. Dopamine neurons derived from embryonic stem cells function in an animal model of Parkinson's disease. Nature 418: 50-56.

Kinder, S.J., Tsang, T.E., Quinlan, G.A., Hadjantonakis, A.K., Nagy, A., and Tam, P.P. 1999. The orderly allocation of mesodermal cells to the extraembryonic structures and the anteroposterior axis during gastrulation of the mouse embryo. Development 126: 4691-4701.

Kingsley, P.D., Malik, J., Fantauzzo, K.A., and Palis, J. 2004. Yolk sac-derived primitive erythroblasts enucleate during mammalian embryogenesis. Blood 104: 19-25.

Klug, M.G., Soonpaa, M.H., Koh, G.Y., and Field, L.J. 1996. Genetically selected cardiomyocytes from differentiating embronic stem cells form stable intracardiac grafts. J. Clin. Invest. 98: 216-224.

Kolossov, E., Fleischmann, B.K., Liu, Q., Bloch, W., ViatchenkoKarpinski, S., Manzke, O., Ji, G.J., Bohlen, H., Addicks, K., and Hescheler, J. 1998. Functional characteristics of ES cellderived cardiac precursor cells identified by tissue-specific expression of the green fluorescent protein. J. Cell Biol. 143: 2045-2056.

Kondo, M., Wagers, A.J., Manz, M.G., Prohaska, S.S., Scherer, D.C., Beilhack, G.F., Shizuru, J.A., and Weissman, I.L. 2003. Biology of hematopoietic stem cells and progenitors: Implications for clinical application. Annu. Rev. Immunol. 21: 759-806.

Kramer, J., Hegert, C., Guan, K., Wobus, A.M., Muller, P.K., and Rohwedel, J. 2000. Embryonic stem cell-derived chondrogenic differentiation in vitro: Activation by BMP-2 and BMP4. Mech. Dev. 92: 193-205.

Ku, H.T., Zhang, N., Kubo, A., O'Connor, R., Mao, M., Keller, G., and Bromberg, J.S. 2004. Committing embryonic stem cells to early endocrine pancreas in vitro. Stem Cells 22: 1205-1217.

Kubo, A., Shinozaki, K., Shannon, J.M., Kouskoff, V., Kennedy, M., Woo, S., Fehling, H.J., and Keller, G. 2004. Development of definitive endoderm from embryonic stem cells in culture. Development 131: 1651-1662.

Kyba, M. and Daley, G.Q. 2003. Hematopoiesis from embryonic stem cells: Lessons from and for ontogeny. Exp. Hematol. 31: 994-1006.

Kyba, M., Perlingeiro, R.C., and Daley, G.Q. 2002. HoxB4 confers definitive lymphoid-myeloid engraftment potential on embryonic stem cell and yolk sac hematopoietic progenitors. Cell 109: 29-37.

Lacaud, G., Gore, L., Kennedy, M., Kouskoff, V., Kingsley, P., Hogan, C., Carlsson, L., Speck, N., Palis, J., and Keller, G. 2002. Runxl is essential for hematopoietic commitment at the hemangioblast stage of development in vitro. Blood 100: 458-466.

Lake, J., Rathjen, J., Remiszewski, J., and Rathjen, P.D. 2000. Reversible programming of pluripotent cell differentiation. 
J. Cell Sci. 113 (Pt 3): 555-566.

Lang, K.J., Rathjen, J., Vassilieva, S., and Rathjen, P.D. 2004. Differentiation of embryonic stem cells to a neural fate: A route to re-building the nervous system? I. Neurosci. Res. 76: 184-192.

Laverriere, A.C., MacNeill, C., Mueller, C., Poelmann, R.E., Burch, J.B., and Evans, T. 1994. GATA-4/5/6, a subfamily of three transcription factors transcribed in developing heart and gut. J. Biol. Chem. 269: 23177-23184.

Lawson, K.A., Dunn, N.R., Roelen, B.A., Zeinstra, L.M., Davis, A.M., Wright, C.V., Korving, J.P., and Hogan, B.L. 1999. Bmp4 is required for the generation of primordial germ cells in the mouse embryo. Genes \& Dev. 13: 424-436.

Lendahl, U., Zimmerman, L.B., and McKay, R.D. 1990. CNS stem cells express a new class of intermediate filament protein. Cell 60: 585-595.

Levenberg, S., Golub, J.S., Amit, M., Itskovitz-Eldor, J., and Langer, R. 2002. Endothelial cells derived from human embryonic stem cells. Proc. Nat1. Acad. Sci. 99: 4391-4396.

Li, M., Pevny, L., Lovell-Badge, R., and Smith, A. 1998. Generation of purified neural precursors from embryonic stem cells by lineage selection. Curr. Biol. 8: 971-974.

Lieber, J.G., Webb, S., Suratt, B.T., Young, S.K., Johnson, G.L., Keller, G.M., and Worthen, G.S. 2004. The in vitro production and characterization of neutrophils from embryonic stem cells. Blood 103: 852-859.

Lin, R.Y., Kubo, A., Keller, G.M., and Davies, T.F. 2003. Committing embryonic stem cells to differentiate into thyrocytelike cells in vitro. Endocrinology 144: 2644-2649.

Liu, S., Qu, Y., Stewart, T.J., Howard, M.J., Chakrabortty, S., Holekamp, T.F., and McDonald, J.W. 2000. Embryonic stem cells differentiate into oligodendrocytes and myelinate in culture and after spinal cord transplantation. Proc. Natl. Acad. Sci. 97: 6126-6131.

Lumelsky, N., Blondel, O., Laeng, P., Velasco, I., Ravin, R., and McKay, R. 2001. Differentiation of embryonic stem cells to insulin-secreting structures similar to pancreatic islets. Science 292: 1389-1394.

Ma, Y., Ramezani, A., Lewis, R., Hawley, R.G., and Thomson, J.A. 2003. High-level sustained transgene expression in human embryonic stem cells using lentiviral vectors. Stem Cells 21: 111-117.

Maltsev, V.A., Rohwedel, J., Hescheler, J., and Wobus, A.M. 1993. Embryonic stem cells differentiate in vitro into cardiomyocytes representing sinusnodal, atrial and ventricular cell types. Mech. Dev. 44: 41-50.

Marchetti, S., Gimond, C., Iljin, K., Bourcier, C., Alitalo, K., Pouyssegur, J., and Pages, G. 2002. Endothelial cells genetically selected from differentiating mouse embryonic stem cells incorporate at sites of neovascularization in vivo. J. Cell Sci. 115: 2075-2085.

Martin, G. 1981. Isolation of a pluripotent cell line from early mouse embryos cultured in medium conditioned by teratocarcinoma stem cells. Proc. Natl. Acad. Sci. 78: 7635.

Matin, M.M., Walsh, J.R., Gokhale, P.J., Draper, J.S., Bahrami, A.R., Morton, I., Moore, H.D., and Andrews, P.W. 2004. Specific knockdown of Oct4 and $\beta 2$-microglobulin expression by RNA interference in human embryonic stem cells and embryonic carcinoma cells. Stem Cells 22: 659-668.

Matsuda, T., Nakamura, T., Nakao, K., Arai, T., Katsuki, M., Heike, T., and Yokota, T. 1999. STAT3 activation is sufficient to maintain an undifferentiated state of mouse embryonic stem cells. EMBO J. 18: 4261-4269.

Matsuyoshi, N., Toda, K., Horiguchi, Y., Tanaka, T., Nakagawa, S., Takeichi, M., and Imamura, S. 1997. In vivo evidence of the critical role of cadherin-5 in murine vascular integrity.
Proc. Assoc. Am. Physicians 109: 362-371.

Matzuk, M.M., Kumar, T.R., and Bradley, A. 1995. Different phenotypes for mice deficient in either activins or activin receptor type II. Nature 374: 356-360.

McDonald, J.W., Liu, X.Z., Qu, Y., Liu, S., Mickey, S.K., Turetsky, D., Gottlieb, D.I., and Choi, D.W. 1999. Transplanted embryonic stem cells survive, differentiate and promote recovery in injured rat spinal cord. Nat. Med. 5: 14101412.

McGrath, K.E. and Palis, J. 1997. Expression of homeobox genes, including an insulin promoting factor, in the murine yolk sac at the time of hematopoietic initiation. Mol. Reprod. Dev. 48: 145-153.

Medvinsky, A. and Dzierzak, E. 1996. Definitive hematopoiesis is autonomously initiated by the AGM region. Cell 86: 897906.

Meehan, R.R., Barlow, D.P., Hill, R.E., Hogan, B.L., and Hastie, N.D. 1984. Pattern of serum protein gene expression in mouse visceral yolk sac and foetal liver. EMBO J. 3: 18811885.

Melloul, D., Marshak, S., and Cerasi, E. 2002. Regulation of insulin gene transcription. Diabetologia 45: 309-326.

Metcalf, D. and Moore, M. 1971. Haemopoietic cells. In Frontiers in biology (eds. A. Neuberger and E.L. Tatum). NorthHolland, London.

Micallef, S.J., Janes, M.E., Knezevic, K., Davis, R.P., Elefanty, A.G., and Stanley, E.G. 2005. Retinoic acid induces Pdx1positive endoderm in differentiating mouse embryonic stem cells. Diabetes 54: 301-305.

Mikkola, H.K., Fujiwara, Y., Schlaeger, T.M., Traver, D., and Orkin, S.H. 2003. Expression of CD41 marks the initiation of definitive hematopoiesis in the mouse embryo. Blood 101: 508-516.

Millauer, B., Wizigmann-Voos, S., Schnurch, H., Martinez, R., Moller, N.P., Risau, W., and Ullrich, A. 1993. High affinity VEGF binding and developmental expression suggest Flk-1 as a major regulator of vasculogenesis and angiogenesis. Cell 72: 835-846.

Min, J.Y., Yang, Y., Converso, K.L., Liu, L., Huang, Q., Morgan, J.P., and Xiao, Y.F. 2002. Transplantation of embryonic stem cells improves cardiac function in postinfarcted rats. J. Appl. Physiol. 92: 288-296.

Min, J.Y., Yang, Y., Sullivan, M.F., Ke, Q., Converso, K.L., Chen, Y., Morgan, J.P., and Xiao, Y.F. 2003. Long-term improvement of cardiac function in rats after infarction by transplantation of embryonic stem cells. J. Thorac. Cardiovasc. Surg. 125: 361-369.

Mitjavila-Garcia, M.T., Cailleret, M., Godin, I., Nogueira, M.M., Cohen-Solal, K., Schiavon, V., Lecluse, Y., Le Pesteur, F., Lagrue, A.H., and Vainchenker, W. 2002. Expression of CD41 on hematopoietic progenitors derived from embryonic hematopoietic cells. Development 129: 2003-2013.

Mitsui, K., Tokuzawa, Y., Itoh, H., Segawa, K., Murakami, M., Takahashi, K., Maruyama, M., Maeda, M., and Yamanaka, S. 2003. The homeoprotein Nanog is required for maintenance of pluripotency in mouse epiblast and ES cells. Cell 113: 631-642.

Miyazaki, S., Yamato, E., and Miyazaki, J. 2004. Regulated expression of pdx-1 promotes in vitro differentiation of insulinproducing cells from embryonic stem cells. Diabetes 53: $1030-1037$.

Monaghan, A.P., Kaestner, K.H., Grau, E., and Schutz, G. 1993. Postimplantation expression patterns indicate a role for the mouse forkhead/HNF- $3 \alpha, \beta$ and $\gamma$ genes in determination of the definitive endoderm, chordamesoderm and neuroectoderm. Development 119: 567-578. 
Moore, M.A. and Metcalf, D. 1970. Ontogeny of the haemopoietic system: Yolk sac origin of in vivo and in vitro colony forming cells in the developing mouse embryo. Br. J. Haematol. 18: 279-296.

Muller, A. and Dzierzak, E. 1993. ES cells have only a limited lymphopoietic potential after adoptive transfer into mouse recipient. Development 118: 1343-1351.

Muller, A.M., Medvinsky, A., Strouboulis, J., Grosveld, F., and Dzierzak, E. 1994. Development of hematopoietic stem cell activity in the mouse embryo. Immunity 1: 291-301.

Muller, M., Fleischmann, B.K., Selbert, S., Ji, G.J., Endl, E., Middeler, G., Muller, O.J., Schlenke, P., Frese, S., Wobus, A.M., et al. 2000. Selection of ventricular-like cardiomyocytes from ES cells in vitro. FASEB J. 14: 2540-2548.

Mummery, C., Ward, D., van den Brink, C.E., Bird, S.D., Doevendans, P.A., Opthof, T., Brutel de la Riviere, A., Tertoolen, L., van der Heyden, M., and Pera, M. 2002. Cardiomyocyte differentiation of mouse and human embryonic stem cells. J. Anat. 200: 233-242.

Mummery, C., Ward-van Oostwaard, D., Doevendans, P., Spijker, R., van den Brink, S., Hassink, R., van der Heyden, M., Opthof, T., Pera, M., de la Riviere, A.B., et al. 2003. Differentiation of human embryonic stem cells to cardiomyocytes: Role of coculture with visceral endoderm-like cells. Circulation 107: 2733-2740.

Munsie, M.J., Michalska, A.E., O'Brien, C.M., Trounson, A.O., Pera, M.F., and Mountford, P.S. 2000. Isolation of pluripotent embryonic stem cells from reprogrammed adult mouse somatic cell nuclei. Curr. Biol. 10: 989-992.

Murray, P.D.F. 1932. The development of in vitro of the blood of the early chick embryo. Proc. Roy. Soc. London 11: 497-521.

Murtaugh, L.C. and Melton, D.A. 2003. Genes, signals, and lineages in pancreas development. Annu. Rev. Cell Dev. Biol. 19: $71-89$.

Nakano, T., Kodama, H., and Honjo, T. 1994. Generation of lymphohematopoietic cells from embryonic stem cells in culture. Science 265: 1098-1101.

Nakayama, N., Lee, J., and Chiu, L. 2000. Vascular endothelial growth factor synergistically enhances bone morphogenetic protein-4-dependent lymphohematopoietic cell generation from embryonic stem cells in vitro. Blood 95: 2275-2283.

Ninomiya, H., Takahashi, S., Tanegashima, K., Yokota, C., and Asashima, M. 1999. Endoderm differentiation and inductive effect of activin-treated ectoderm in Xenopus. Dev. Growth Differ. 41: 391-400.

Nir, S.G., David, R., Zaruba, M., Franz, W.M., and ItskovitzEldor, J. 2003. Human embryonic stem cells for cardiovascular repair. Cardiovasc. Res. 58: 313-323.

Nishikawa, S., Nishikawa, S., Hirashima, M., Matsuyoshi, N., and Kodama, H. 1998. Progressive lineage analysis by cell sorting and culture identifies FLK+VE-cadherin cells at a diverging point of endothelial and hemopoietic lineages. Development 125: 1747-1757.

Niwa, H., Burdon, T., Chambers, I., and Smith, A. 1998. Selfrenewal of pluripotent embryonic stem cells is mediated via activation of STAT3. Genes \& Dev. 12: 2048-2060.

Niwa, H., Miyazaki, J., and Smith, A.G. 2000. Quantitative expression of Oct-3/4 defines differentiation, dedifferentiation or self-renewal of ES cells. Nat. Genet. 24: 372-376.

Odorico, J.S., Kaufman, D.S., and Thomson, J.A. 2001. Multilineage differentiation from human embryonic stem cell lines. Stem Cells 19: 193-204.

Ogawa, E., Inuzuka, M., Maruyama, M., Satake, M., Naito-Fujimoto, M., Ito, Y., and Shigesada, K. 1993. Molecular cloning and characterization of PEBP2 $\beta$, the heterodimeric partner of a novel Drosophila runt-related DNA binding protein
PEBP2 $\alpha$. Virology 194: 314-331.

Okabe, S., Forsberg-Nilsson, K., Spiro, A.C., Segal, M., and McKay, R.D. 1996. Development of neuronal precursor cells and functional postmitotic neurons from embryonic stem cells in vitro. Mech. Dev. 59: 89-102.

Okuda, T., van Deursen, J., Hiebert, S.W., Grosveld, G., and Downing, J.R. 1996. AML1, the target of multiple chromosomal translocations in human leukemia, is essential for normal fetal liver hematopoiesis. Cell 84: 321-330.

Orkin, S. 1992. GATA-binding transcription factors in hematopoietic cells. Blood 80: $575-581$.

Overturf, K., al-Dhalimy, M., Ou, C.N., Finegold, M., and Grompe, M. 1997. Serial transplantation reveals the stemcell-like regenerative potential of adult mouse hepatocytes. Am. J. Pathol. 151: 1273-1280.

Palis, J., McGrath, K.E., and Kingsley, P.D. 1995. Initiation of hematopoiesis and vasculogenesis in murine yolk sac explants. Blood 86: 156-163.

Palis, J., Roberston, S., Kennedy, M., Wall, C., and Keller, G. 1999. Development of erythroid and myeloid progenitors in the yolk sac and embryo proper of the mouse. Development 126: $5073-5084$.

Parisi, S., D'Andrea, D., Lago, C.T., Adamson, E.D., Persico, M.G., and Minchiotti, G. 2003. Nodal-dependent Cripto signaling promotes cardiomyogenesis and redirects the neural fate of embryonic stem cells. J. Cell Biol. 163: 303-314.

Park, C., Afrikanova, I., Chung, Y.S., Zhang, W.J., Arentson, E., Fong Gh, G., Rosendahl, A., and Choi, K. 2004. A hierarchical order of factors in the generation of FLK1- and SCL-expressing hematopoietic and endothelial progenitors from embryonic stem cells. Development 131: 2749-2762.

Pera, M.F. and Trounson, A.O. 2004. Human embryonic stem cells: Prospects for development. Development 131: 55155525.

Pera, M.F., Andrade, J., Houssami, S., Reubinoff, B., Trounson, A., Stanley, E.G., Ward-van Oostwaard, D., and Mummery, C. 2004. Regulation of human embryonic stem cell differentiation by BMP-2 and its antagonist noggin. J. Cell Sci. 117: 1269-1280.

Perrier, A.L., Tabar, V., Barberi, T., Rubio, M.E., Bruses, J., Topf, N., Harrison, N.L., and Studer, L. 2004. Derivation of midbrain dopamine neurons from human embryonic stem cells. Proc. Nat1. Acad. Sci. 101: 12543-12548.

Pevny, L., Simon, M.C., Robertson, E., Klein, W.H., Tsai, S.F., D'Agati, V., Orkin, S.H., and Costantini, F. 1991. Erythroid differentiation in chimaeric mice blocked by a targeted mutation in the gene for transcription factor GATA-1. Nature 349: $257-260$.

Phillips, D.R., Charo, I.F., Parise, L.V., and Fitzgerald, L.A. 1988. The platelet membrane glycoprotein IIb-IIIa complex. Blood 71: 831-843.

Pinto do, O.P., Kolterud, A., and Carlsson, L. 1998. Expression of the LIM-homeobox gene LH2 generates immortalized steel factor-dependent multipotent hematopoietic precursors. EMBO J. 17: 5744-5756.

Porcher, C., Swat, W., Rockwell, K., Fujiwara, Y., Alt, F.W., and Orkin, S.H. 1996. The T cell leukemia oncoprotein SCL/ tal-1 is essential for development of all hematopoietic lineages. Cell 86: 47-57.

Rajagopal, J., Anderson, W.J., Kume, S., Martinez, O.I., and Melton, D.A. 2003. Insulin staining of ES cell progeny from insulin uptake. Science 299: 363.

Rambhatla, L., Chiu, C.P., Kundu, P., Peng, Y., and Carpenter, M.K. 2003. Generation of hepatocyte-like cells from human embryonic stem cells. Cell Transplant 12: 1-11.

Rathjen, J., Lake, J.A., Bettess, M.D., Washington, J.M., Chap- 
man, G., and Rathjen, P.D. 1999. Formation of a primitive ectoderm like cell population, EPL cells, from ES cells in response to biologically derived factors. J. Cell Sci. 112 (Pt 5): 601-612.

Reubinoff, B.E., Pera, M.F., Fong, C.Y., Trounson, A., and Bongso, A. 2000. Embryonic stem cell lines from human blastocysts: Somatic differentiation in vitro. Nat. Biotechnol. 18: 399-404.

Reubinoff, B.E., Itsykson, P., Turetsky, T., Pera, M.F., Reinhartz, E., Itzik, A., and Ben-Hur, T. 2001. Neural progenitors from human embryonic stem cells. Nat. Biotechnol. 19: 1134-1140.

Richards, M., Tan, S.P., Tan, J.H., Chan, W.K., and Bongso, A. 2004. The transcriptome profile of human embryonic stem cells as defined by SAGE. Stem Cells 22: 51-64.

Rideout III, W.M., Hochedlinger, K., Kyba, M., Daley, G.Q., and Jaenisch, R. 2002. Correction of a genetic defect by nuclear transplantation and combined cell and gene therapy. Cell 109: 17-27.

Rippon, H.J. and Bishop, A.E. 2004. Embryonic stem cells. Cell Prolif. 37: 23-34.

Robb, L., Lyons, I., Li, R., Hartley, L., Kontgen, F., Harvey, R.P., Metcalf, D., and Begley, C.G. 1995. Absence of yolk sac hematopoiesis from mice with a targeted disruption of the scl gene. Proc. Natl. Acad. Sci. 92: 7075-7079.

Robertson, S.M., Kennedy, M., Shannon, J.M., and Keller, G. 2000. A transitional stage in the commitment of mesoderm to hematopoiesis requiring the transcription factor SCL/tal1. Development 127: 2447-2459.

Rogers, M.B., Hosler, B.A., and Gudas, L.J. 1991. Specific expression of a retinoic acid-regulated, zinc-finger gene, Rex-1, in preimplantation embryos, trophoblast and spermatocytes. Development 113: 815-824.

Rohwedel, J., Maltsev, V., Bober, E., Arnold, H.H., Hescheler, J., and Wobus, A.M. 1994. Muscle cell differentiation of embryonic stem cells reflects myogenesis in vivo: Developmentally regulated expression of myogenic determination genes and functional expression of ionic currents. Dev. Biol. 164: 87-101.

Rossant, J. 1977. Cell commitment in early rodent development. Dev. Mamm. 2: 119-150.

Russel, E. 1979. Heriditary anemias of the mouse: A review for geneticists. Adv. Genet. 20: 357-459.

Sabin, F.R. 1920. Studies on the origin of blood vessels and of red corpuscles as seen in the living blastoderm of the chick during the second day of incubation. Contrib. Embryol. 9: 213262.

Sasai, Y., Lu, B., Steinbeisser, H., and De Robertis, E.M. 1995. Regulation of neural induction by the Chd and Bmp-4 antagonistic patterning signals in Xenopus. Nature 376: 333336.

Sasaki, H. and Hogan, B.L. 1993. Differential expression of multiple fork head related genes during gastrulation and axial pattern formation in the mouse embryo. Development 118: $47-59$.

Sato, N., Meijer, L., Skaltsounis, L., Greengard, P., and Brivanlou, A.H. 2004. Maintenance of pluripotency in human and mouse embryonic stem cells through activation of Wnt signaling by a pharmacological GSK-3-specific inhibitor. Nat. Med. 10: 55-63.

Schier, A.F. and Shen, M.M. 2000. Nodal signalling in vertebrate development. Nature 403: 385-389.

Schmitt, R., Bruyns, E., and Snodgrass, H. 1991. Hematopoietic development of embryonic stem cells in vitro: Cytokine and receptor gene expression. Genes \& Dev. 5: 728-740.

Schmitt, T.M., de Pooter, R.F., Gronski, M.A., Cho, S.K.,
Ohashi, P.S., and Zuniga-Pflucker, J.C. 2004. Induction of $\mathrm{T}$ cell development and establishment of $\mathrm{T}$ cell competence from embryonic stem cells differentiated in vitro. Nat. Immunol. 5: 410-417.

Schroeder, T., Fraser, S.T., Ogawa, M., Nishikawa, S., Oka, C., Bornkamm, G.W., Honjo, T., and Just, U. 2003. Recombination signal sequence-binding protein $\mathrm{J} \kappa$ alters mesodermal cell fate decisions by suppressing cardiomyogenesis. Proc. Natl. Acad. Sci. 100: 4018-4023.

Schuldiner, M., Yanuka, O., Itskovitz-Eldor, J., Melton, D.A., and Benvenisty, N. 2000. Effects of eight growth factors on the differentiation of cells derived from human embryonic stem cells. Proc. Nat1. Acad. Sci. 97: 11307-11312.

Sellem, C.H., Frain, M., Erdos, T., and Sala-Trepat, J.M. 1984. Differential expression of albumin and $\alpha$-fetoprotein genes in fetal tissues of mouse and rat. Dev. Biol. 102: 51-60.

Shalaby, F., Rossant, J., Yamaguchi, T.P., Gertsenstein, M., Wu, X.-F., Breitman, M.L., and Schuh, A.C. 1995. Failure of blood-island formation and vasculogenesis in Flk-1 deficient mice. Nature 376: 62-66.

Shivdasani, R., Mayer, E., and Orkin, S.H. 1995. Absence of blood formation in mice lacking the T-cell leukemia oncoprotein tal-1/SCL. Nature 373: 432-434.

Simon, H.H., Bhatt, L., Gherbassi, D., Sgado, P., and Alberi, L. 2003. Midbrain dopaminergic neurons: Determination of their developmental fate by transcription factors. Ann. NY Acad. Sci. 991: 36-47.

Sipione, S., Eshpeter, A., Lyon, J.G., Korbutt, G.S., and Bleackley, R.C. 2004. Insulin expressing cells from differentiated embryonic stem cells are not $\beta$ cells. Diabetologia 47: 499508.

Smith, A.G. 2001. Embryo-derived stem cells: Of mice and men. Annu. Rev. Cell Dev. Biol. 17: 435-462.

Smith, A.G., Heath, J.K., Donaldson, D.D., Wong, G.G., Moreau, J., Stahl, M., and Rogers, D. 1988. Inhibition of pluripotential embryonic stem cell differentiation by purified polypeptides. Nature 336: 688-690.

Snir, M., Kehat, I., Gepstein, A., Coleman, R., Itskovitz-Eldor, J., Livne, E., and Gepstein, L. 2003. Assessment of the ultrastructural and proliferative properties of human embryonic stem cell-derived cardiomyocytes. Am. I. Physiol. Heart Circ. Physiol. 285: H2355-H2363.

Soria, B., Roche, E., Berna, G., Leon-Quinto, T., Reig, J.A., and Martin, F. 2000. Insulin-secreting cells derived from embryonic stem cells normalize glycemia in streptozotocininduced diabetic mice. Diabetes 49: 157-162.

Soudais, C., Bielinska, M., Heikinheimo, M., MacArthur, C.A., Narita, N., Saffitz, J.E., Simon, M.C., Leiden, J.M., and Wilson, D.B. 1995. Targeted mutagenesis of the transcription factor GATA-4 gene in mouse embryonic stem cells disrupts visceral endoderm differentiation in vitro. Development 121: 3877-3888.

Stamatoyannopoulos, G. and Grosveld, F. 2001. Hemoglobin switching. In The molecular basis of blood diseases (eds. G. Stamatoyannopoulos et al.), pp. 135-165. W.B. Saunders, New York.

Stewart, C.L., Kaspar, P., Brunet, L.J., Bhatt, H., Gadi, I., Kontgen, F., and Abbondanzo, S.J. 1992. Blastocyst implantation depends on maternal expression of leukaemia inhibitory factor [see comments]. Nature 359: 76-79.

Stoffel, M., Vallier, L., and Pedersen, R.A. 2004. Navigating the pathway from embryonic stem cells to $\beta$ cells. Semin. Cell Dev. Biol. 15: 327-336.

Sun, X., Meyers, E.N., Lewandoski, M., and Martin, G.R. 1999. Targeted disruption of Fgf8 causes failure of cell migration in the gastrulating mouse embryo. Genes \& Dev. 13: 1834-1846. 
Takahashi, T., Lord, B., Schulze, P.C., Fryer, R.M., Sarang, S.S., Gullans, S.R., and Lee, R.T. 2003. Ascorbic acid enhances differentiation of embryonic stem cells into cardiac myocytes. Circulation 107: 1912-1916.

Takakura, N., Huang, X.L., Naruse, T., Hamaguchi, I., Dumont, D.J., Yancopoulos, G.D., and Suda, T. 1998. Critical role of the TIE2 endothelial cell receptor in the development of definitive hematopoiesis. Immunity 9: 677-686.

Tam, P.P. and Behringer, R.R. 1997. Mouse gastrulation: The formation of a mammalian body plan. Mech. Dev. 68: 3-25.

Thomas, P. and Beddington, R. 1996. Anterior primitive endoderm may be responsible for patterning the anterior neural plate in the mouse embryo. Curr. Biol. 6: 1487-1496.

Thomson, J.A., Itskovitz-Eldor, J., Shapiro, S.S., Walnitz, M.A., Swiergiel, J.J., Marshall, V.S., and Jones, J.M. 1998. Embryonic stem cell lines derived from human blastocysts. Science 282: $1145-1147$.

Toyooka, Y., Tsunekawa, N., Akasu, R., and Noce, T. 2003. Embryonic stem cells can form germ cells in vitro. Proc. Nat1. Acad. Sci. 100: 11457-11462.

Tropepe, V., Hitoshi, S., Sirard, C., Mak, T.W., Rossant, J., and van der Kooy, D. 2001. Direct neural fate specification from embryonic stem cells: A primitive mammalian neural stem cell stage acquired through a default mechanism. Neuron 30: $65-78$.

Tsai, M., Wedemeyer, J., Ganiatsas, S., Tam, S.Y., Zon, L.I., and Galli, S.J. 2000. In vivo immunological function of mast cells derived from embryonic stem cells: An approach for the rapid analysis of even embryonic lethal mutations in adult mice in vivo. Proc. Natl. Acad. Sci. 97: 9186-9190.

Vassalli, A., Matzuk, M.M., Gardner, H.A., Lee, K.F., and Jaenisch, R. 1994. Activin/inhibin $\beta$ B subunit gene disruption leads to defects in eyelid development and female reproduction. Genes \& Dev. 8: 414-427.

Velkey, J.M. and O'Shea, K.S. 2003. Oct4 RNA interference induces trophectoderm differentiation in mouse embryonic stem cells. Genesis 37: 18-24.

Verlinsky, Y., Strelchenko, N., Kukharenko, V., Rechitsky, S., Verlinsky, O., Galat, V., and Kuliev, A. 2005. Human embryonic stem cell lines with genetic disorders. Reprod. Biomed. Online 10: 105-110.

Vittet, D., Prandini, M.H., Berthier, R., Schweitzer, A., MartinSisteron, H., Uzan, G., and Dejana, E. 1996. Embryonic stem cells differentiate in vitro to endothelial cells through successive maturation steps. Blood 88: 3424-3431.

Vodyanik, M.A., Bork, J.A., Thomson, J.A., and Slukvin, I.I. 2005. Human embryonic stem cell-derived CD $34^{+}$cells: Efficient production in the coculture with OP9 stromal cells and analysis of lymphohematopoietic potential. Blood 105: 617-626.

Wakayama, T., Tabar, V., Rodriguez, I., Perry, A.C., Studer, L., and Mombaerts, P. 2001. Differentiation of embryonic stem cell lines generated from adult somatic cells by nuclear transfer. Science 292: 740-743.

Wang, S.W. and Speck, N.A. 1992. Purification of core-binding factor, a protein that binds the conserved core site in murine leukemia virus enhancers. Mol. Cell. Biol. 12: 89-102.

Wang, R., Clark, R., and Bautch, V.L. 1992. Embryonic stem cell-derived cystic embryoid bodies form vascular channels: An in vitro model of blood vessel development. Development 114: 303-316.

Wang, Q., Stacy, T., Binder, M., Marin-Padilla, M., Sharpe, A., and Speck, N. 1996. Disruption of the Cbfa2 gene causes necrosis and hemorraging in the central nervous system andblocks definitive hematopoiesis. Proc. Natl. Acad. Sci. 93: 3444-3449.
Wang, L., Li, L., Shojaei, F., Levac, K., Cerdan, C., Menendez, P., Martin, T., Rouleau, A., and Bhatia, M. 2004. Endothelial and hematopoietic cell fate of human embryonic stem cells originates from primitive endothelium with hemangioblastic properties. Immunity 21: 31-41.

Wang, Z., Cohen, K., Shao, Y., Mole, P., Dombkowski, D., and Scadden, D.T. 2004. Ephrin receptor, EphB4, regulates ES cell differentiation of primitive mammalian hemangioblasts, blood, cardiomyocytes, and blood vessels. Blood 103: 100-109.

Watt, S.M., Gschmeissner, S.E., and Bates, P.A. 1995. PECAM1: Its expression and function as a cell adhesion molecule on hemopoietic and endothelial cells. Leuk. Lymphoma 17: 229-244.

Weiss, M., Keller, G., and Orkin, S. 1994. Novel insights into erythroid development revealed through in vitro differentiation of GATA-1-embryonic stem cells. Genes \& Dev. 8: 1184-1197.

Wert, S.E., Glasser, S.W., Korfhagen, T.R., and Whitsett, J.A. 1993. Transcriptional elements from the human SP-C gene direct expression in the primordial respiratory epithelium of transgenic mice. Dev. Biol. 156: 426-443.

West, J.A. and Daley, G.Q. 2004. In vitro gametogenesis from embryonic stem cells. Curr. Opin. Cell Biol. 16: 688692.

Whitman, M. 2001. Nodal signaling in early vertebrate embryos: Themes and variations. Dev. Cell 1: 605-617.

Wichterle, H., Lieberam, I., Porter, J.A., and Jessell, T.M. 2002. Directed differentiation of embryonic stem cells into motor neurons. Cell 110: 385-397.

Wiles, M.V. and Johansson, B.M. 1999. Embryonic stem cell development in a chemically defined medium. Exp. Cell Res. 247: 241-248.

Williams, R.L., Hilton, D.J., Pease, S., Willson, T.A., Stewart, C.L., Gearing, D.P., Wagner, E.F., Metcalf, D., Nicola, N.A., and Gough, N.M. 1988. Myeloid leukaemia inhibitory factor maintains the developmental potential of embryonic stem cells. Nature 336: 684-687.

Wilson, P.A., Lagna, G., Suzuki, A., and Hemmati-Brivanlou, A. 1997. Concentration-dependent patterning of the Xenopus ectoderm by BMP4 and its signal transducer Smad1. Development 124: 3177-3184.

Xu, C., Inokuma, M.S., Denham, J., Golds, K., Kundu, P., Gold, J.D., and Carpenter, M.K. 2001. Feeder-free growth of undifferentiated human embryonic stem cells. Nat. Biotechnol. 19: 971-974.

Xu, R.H., Chen, X., Li, D.S., Li, R., Addicks, G.C., Glennon, C., Zwaka, T.P., and Thomson, J.A. 2002. BMP4 initiates human embryonic stem cell differentiation to trophoblast. Nat. Biotechnol. 20: 1261-1264.

Yamada, T., Yoshikawa, M., Kanda, S., Kato, Y., Nakajima, Y., Ishizaka, S., and Tsunoda, Y. 2002a. In vitro differentiation of embryonic stem cells into hepatocyte-like cells identified by cellular uptake of indocyanine green. Stem Cells 20: 146154.

Yamada, T., Yoshikawa, M., Takaki, M., Torihashi, S., Kato, Y., Nakajima, Y., Ishizaka, S., and Tsunoda, Y. 2002b. In vitro functional gut-like organ formation from mouse embryonic stem cells. Stem Cells 20: 41-49.

Yamaguchi, T.P. 2001. Heads or tails: Wnts and anterior-posterior patterning. Curr. Biol. 11: R713-R724.

Yamaguchi, T.P. and Rossant, J. 1995. Fibroblast growth factors in mammalian development. Curr. Opin. Genet. Dev. 5: 485-491.

Yamaguchi, T.P., Dumont, D.J., Conlon, R.A., Breitman, M.L., and Rossant, J. 1993. flk-1, an flt-related receptor tyrosine 
kinase is an early marker for endothelial cell precursors. Development 118: 489-498.

Yamashita, J., Itoh, H., Hirashima, M., Ogawa, M., Nishikawa, S., Yurugi, T., Naito, M., and Nakao, K. 2000. Flk1-positive cells derived from embryonic stem cells serve as vascular progenitors. Nature 408: 92-96.

Yang, Y., Min, J.Y., Rana, J.S., Ke, Q., Cai, J., Chen, Y., Morgan, J.P., and Xiao, Y.F. 2002. VEGF enhances functional improvement of postinfarcted hearts by transplantation of ESCdifferentiated cells. J. Appl. Physiol. 93: 1140-1151.

Ye, W., Shimamura, K., Rubenstein, J.L., Hynes, M.A., and Rosenthal, A. 1998. FGF and Shh signals control dopaminergic and serotonergic cell fate in the anterior neural plate. Cell 93: 755-766.

Ying, Q.L., Nichols, J., Chambers, I., and Smith, A. 2003a. BMP induction of Id proteins suppresses differentiation and sustains embryonic stem cell self-renewal in collaboration with STAT3. Cell 115: 281-292.

Ying, Q.L., Stavridis, M., Griffiths, D., Li, M., and Smith, A. 2003b. Conversion of embryonic stem cells into neuroectodermal precursors in adherent monoculture. Nat. Biotechnol. 21: 183-186.

Yoshida, H., Hayashi, S., Kunisada, T., Ogawa, M., Nishikawa, S., Okamura, H., Sudo, T., and Shultz, L.D. 1990. The murine mutation osteopetrosis is in the coding region of the macrophage colony stimulating factor gene. Nature 345: 442-444.

Young, P.E., Baumhueter, S., and Lasky, L.A. 1995. The sialomucin CD34 is expressed on hematopoietic cells and blood vessels during murine development. Blood 85: 96-105.

Yurugi-Kobayashi, T., Itoh, H., Yamashita, J., Yamahara, K., Hirai, H., Kobayashi, T., Ogawa, M., Nishikawa, S., and Nakao, K. 2003. Effective contribution of transplanted vascular progenitor cells derived from embryonic stem cells to adult neovascularization in proper differentiation stage. Blood 101: 2675-2678.

Zandstra, P.W., Bauwens, C., Yin, T., Liu, Q., Schiller, H., Zweigerdt, R., Pasumarthi, K.B., and Field, L.J. 2003. Scalable production of embryonic stem cell-derived cardiomyocytes. Tissue Eng. 9: 767-778.

Zeng, X., Cai, J., Chen, J., Luo, Y., You, Z.B., Fotter, E., Wang, Y., Harvey, B., Miura, T., Backman, C., et al. 2004. Dopaminergic differentiation of human embryonic stem cells. Stem Cells 22: 925-940.

Zhang, S.C., Wernig, M., Duncan, I.D., Brustle, O., and Thomson, J.A. 2001. In vitro differentiation of transplantable neural precursors from human embryonic stem cells. Nat. Biotechnol. 19: 1129-1133.

Zippo, A., De Robertis, A., Bardelli, M., Galvagni, F., and Oliviero, S. 2004. Identification of Flk-1 target genes in vasculogenesis: Pim-1 is required for endothelial and mural cell differentiation in vitro. Blood 103: 4536-4544.

zur Nieden, N.I., Kempka, G., and Ahr, H.J. 2003. In vitro differentiation of embryonic stem cells into mineralized osteoblasts. Differentiation 71: 18-27.

Zwaka, T.P. and Thomson, J.A. 2003. Homologous recombination in human embryonic stem cells. Nat. Biotechnol. 21: 319-321. 


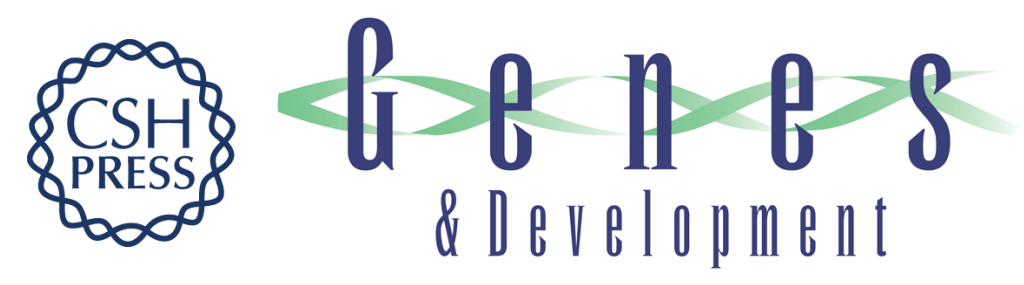

\section{Embryonic stem cell differentiation: emergence of a new era in biology and medicine}

Gordon Keller

Genes Dev. 2005, 19:

Access the most recent version at doi:10.1101/gad.1303605

$\begin{array}{ll}\text { References } & \text { This article cites } 269 \text { articles, } 110 \text { of which can be accessed free at: } \\ \text { http://genesdev.cshlp.org/content/19/10/1129.full.html\#ref-list-1 }\end{array}$

License

Email Alerting Receive free email alerts when new articles cite this article - sign up in the box at the top Service right corner of the article or click here.

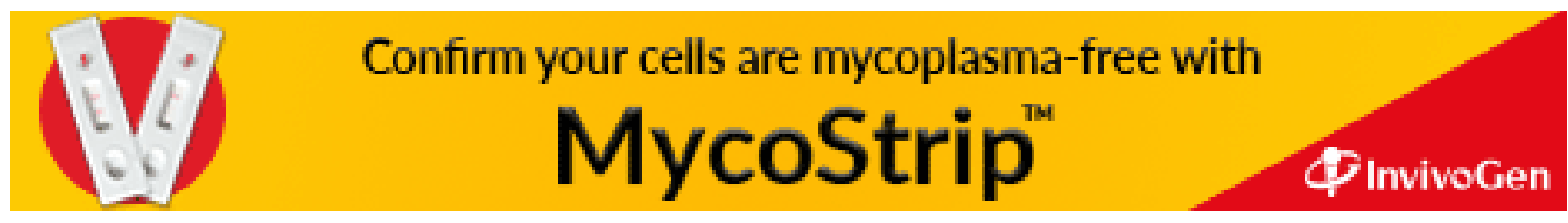

